\title{
A conceptual framework for a sports knee injury performance profile (SKIPP) and return to activity criteria (RTAC)
}

\author{
David Logerstedt ${ }^{1}$, Amelia Arundale ${ }^{2}$, Andrew Lynch ${ }^{3,4}$, \\ Lynn Snyder-Mackler ${ }^{2,5}$
}

\begin{abstract}
Injuries to the knee, including intra-articular fractures, ligamentous ruptures, and meniscal and articular cartilage lesions, are commonplace within sports. Despite advancements in surgical techniques and enhanced rehabilitation, athletes returning to cutting, pivoting, and jumping sports after a knee injury are at greater risk of sustaining a second injury. The clinical utility of objective criteria presents a decision-making challenge to ensure athletes are fully rehabilitated and safe to return to sport. A system centered on specific indicators that can be used to develop a comprehensive profile to monitor rehabilitation progression and to establish return to activity criteria is recommended to clear athletes to begin a progressive and systematic approach to activities and sports. Integration of a sports knee injury performance profile with return to activity criteria can guide clinicians in facilitating an athlete's safe return to sport, prevention of subsequent injury, and life-long knee joint health.
\end{abstract}

Keywords: lower extremity; limb symmetry; sports readiness; athletes.

\section{HOW TO CITE THIS ARTICLE}

Logerstedt D, Arundale A, Lynch A, Snyder-Mackler L. A conceptual framework for a sports knee injury performance profile (SKIPP) and return to activity criteria (RTAC). Braz J Phys Ther. 2015 Sept-Oct; 19(5):340-359. http://dx.doi.org/10.1590/bjpt-rbf.2014.0116

\section{Introduction}

The burden of musculoskeletal (MSK) injuries on the health of our population is substantial as more than 110 million adults reported musculoskeletal injuries in $2008^{1}$. MSK injuries are the leading cause of disability in the Unites States with annual direct and indirect costs totaling $\$ 950$ billion $^{2}$. MSK injuries can be the result of trauma, overuse, or a combination of acute on chronic injury leading to impaired function and reduced quality of life.

The knee is one of the most frequently injured joints in physically active individuals ${ }^{3-5}$. Many of these injuries, such as intra-articular fractures, ligamentous ruptures, and meniscal and articular cartilage injuries ${ }^{6}$, are traumatic in nature and occur during sports involving jumping, cutting, and pivoting 7 . Surgery for such knee injuries is common, totaling 984,607 arthroscopic knee surgeries performed in the US alone in $2006^{8}$.

Traumatic knee injuries increase risk for the development of post-traumatic osteoarthritis (PTOA).
Individuals with a previous knee injury have a $56.8 \%$ lifetime risk of development of knee osteoarthritis $(\mathrm{OA})^{9}$, resulting in activity limitations and participation restrictions. Furthermore, $13-18 \%$ of patients with total joint replacement report an identifiable traumatic injury to the joint ${ }^{10}$. Brown et al. ${ }^{11}$ estimated that 5.6 million individuals in the United States have PTOA, resulting in annual costs of $\$ 3.06$ billion. Despite the short-term and long-term risks, many athletes desire to return to cutting and pivoting sports, which increases the risk of additional injuries.

Safe return to sports after a traumatic injury is the responsibility of all healthcare professionals involved. Despite best efforts, athletes returning to high-risk activity and demanding sports after a knee injury are at greater risk of sustaining a second injury. Many post-surgical rehabilitation guidelines are based solely on time from surgery and permit individuals to return to sports-specific activities between 4-9 months;

\footnotetext{
'Department of Physical Therapy, University of the Sciences, Philadelphia, PA, USA

${ }^{2}$ Interdisciplinary Program in Biomechanics and Movement Science, University of Delaware, Newark, DE, USA

${ }^{3}$ Department of Physical Therapy, University of Pittsburgh, Pittsburgh, PA, USA

${ }^{4}$ Center for Sports Medicine, University of Pittsburgh Medical Center, Pittsburgh, PA, USA

${ }_{5}^{5}$ Department of Physical Therapy, University of Delaware, Newark, DE, USA

Received: Mar. 09, 2015 Revised: June 11, 2015 Accepted: June 18, 2015
} 
however, very few guidelines provide any objective criteria for assessing an athlete's readiness ${ }^{12}$. The lack of clear objective criteria measuring patient function in sport-specific activities, and for returning to sports may place the injured athlete at risk for re-injury or suboptimal performance. Objective criteria are critical to ensure that athletes are fully rehabilitated and their knees are ready to meet the demands of their sport. Recovery of full function, return to prior activities, and long-term joint health are all goals of the athlete, surgeon, and physical therapist; yet there is little consensus to guide clinicians in facilitating an athlete's safe return to sport, prevention of subsequent injury, and life-long knee joint health.

Currently, there is no system centered on specific indicators that can be used to develop a comprehensive profile to monitor rehabilitation progression and to compile all individualized data to standardize education about the risks of re-injury to the knee and the likelihood of returning to sports. The utilization of these profiles may provide a more accurate and complete representation of an athlete's current status. The purpose of this paper is to build on the conceptual framework for the restoration of limb-to-limb symmetry in its role of secondary and tertiary knee injury prevention by 1) reviewing the epidemiology related to traumatic knee injuries, 2) identifying the risk factors that are associated with re-injury and poor knee function, 3) providing recommendations for objective measures utilizing limb-to-limb symmetry as a performance-based criteria for readiness to return to activity.

\section{Epidemiology of traumatic knee injuries}

\section{Prevalence}

While it is difficult to quantify the number of anterior cruciate ligament (ACL) injuries, recent estimates in the US have reported 81 per 100,000 individuals between the ages of 10 and 64 or about 250,000 per year ${ }^{13-15}$ with over 127,000 arthroscopic ACL reconstructions $(\mathrm{ACLR})^{8}$. ACL surgeries account for $12.9 \%$ of all arthroscopic knee surgeries ${ }^{8}$. ACL injuries often are not isolated; $43-70 \%$ of those undergoing ACLR have meniscal lesions, $20-25 \%$ have cartilage lesions (about 5\% full-thickness) and over $80 \%$ have bone bruises $^{16-18}$.

Meniscal injuries are the fourth most common knee injury in high school athletes ${ }^{19}$. In 2006, medial and lateral meniscal surgeries were the first and third most common arthroscopic surgeries, respectively ${ }^{8}$. In a six-year study encompassing approximately $9 \%$ of the US population under the age of 65 , there were 387,833 meniscectomies, 23,640 meniscal repairs, and 84,927 ACLR with associated meniscal surgery. Over the six-year time frame, the number of meniscectomies decreased in favor of meniscal repairs $^{20}$, a trend recommended by literature due to the impact on OA. Similar to ACL injuries, meniscal injuries are not common in isolation ${ }^{18}$.

Almost one million individuals are affected annually by articular cartilage injuries ${ }^{21,22}$. The prevalence of cartilage lesions in the general population is estimated between $5-11 \%$, however in recreational and professional athletes the prevalence is $35 \%{ }^{23}$ and higher in athletes participating in cutting and pivoting sports $^{21,22}$. Upwards of $50 \%$ of adolescent athletes participating in cutting and pivoting sports undergoing knee surgery have articular cartilage injuries ${ }^{24}$, and when considering all patients undergoing knee arthroscopy, the prevalence is between $60-70 \%{ }^{25-28}$. Small asymptomatic lesions left untreated can increase in size, resulting in a painful knee joint ${ }^{29}$. Thirty-two to $58 \%$ of articular cartilage lesions are the result of a traumatic, noncontact mechanism of injury ${ }^{25,29,30}$, and as might be expected, nearly three-quarters are concomitant with ACL injuries ${ }^{17,18}$. Articular cartilage damage after traumatic knee injuries increases the risk of cartilage degradation in all three knee compartments ${ }^{24}$. Consequently, articular cartilage damage is a strong risk factor for the development of osteoarthritis after knee surgeries $^{31,32}$.

\section{Failure/Re-injury}

Overall, the risk of ACL injury in an athlete with a history of ACLR is 15 times greater than that of a healthy athlete ${ }^{33}$, with an incidence of injury to either the contralateral or ipsilateral knee between 3 and $49 \%{ }^{33,34}$. Athletes with allografts are five times more likely to require a revision compared to those with autografts ${ }^{35}$. There is no significant difference in second injuries between athletes with hamstring autografts and bone-patella-tendon-bone (BPTB) autografts; however, at 15-year follow-up, there were more ipsilateral injuries in the hamstring group and more contralateral injuries in the BPTB group ${ }^{36}$. Returning to cutting/pivoting sports increases the odds of ipsilateral injury 3.9 fold and contralateral 5 fold $^{37}$. Furthermore, positive family history doubles the odds for both ipsilateral and contralateral rupture ${ }^{37}$. Injury 
side (contralateral vs ipsilateral) is associated with age and graft angle, respectively ${ }^{38}$.

Women with a history of ACL injury are at greater risk of a second ACL injury with 16 -fold greater risk of injury compared to healthy controls and four times greater risk than men with a history of ACLR ${ }^{33}$. While most studies have reported an overall greater number of contralateral injuries compared to ipsilateral graft injuries $^{33,38-40}$, women are six times more likely to suffer a contralateral injury ${ }^{33,40}$, whereas, men are three times more likely to injure their reconstructed graft ${ }^{36}$.

Younger athletes have greater rates of re-injury within 2 years of ACLR, with $17 \%$ of those under the age of 18 having a second ACL injury compared to $7 \%$ of those between 18 and 25 , and only $4 \%$ of those over $25^{40}$. At three-year follow-up, $29 \%$ of those under the age of 20 had a second injury, the highest incidence of any age group ${ }^{37}$. When compared to the older age groups, the youngest age group had a six-fold increase in risk for ipsilateral and three-fold increase for contralateral injury ${ }^{37}$. Leys et al. ${ }^{36}$ calculated an odds ratio of 4.1 for contralateral injury in those under 18. In collegiate athletes, more athletes who had a primary ACLR prior to college went on to have a second injury compared to those who had their primary ACLR during college ${ }^{41}$.

Failure for all meniscal surgeries ranges from 20.2-24.3\%, depending on the type of meniscal surgery and status of the $\mathrm{ACL}^{42}$. Athletes with meniscal repair and concomitant ACLR have a lower risk of revision for their meniscus injury ${ }^{43-45}$, suggesting that restoring passive knee stability reduces the incidence of further meniscal damage. Isolated lateral meniscal injury, earlier surgery, older age, and surgeons performing a high volume of meniscal repairs per year also decreases risk of revision ${ }^{43,44}$. Subsequent operation rates are greater for meniscal repairs compared to partial meniscectomies, greater for partial lateral meniscectomies compared partial medial meniscectomies, and greater for medial meniscus repairs compared to lateral meniscus repairs ${ }^{46}$.

After microfracture, those with a single defect have a lesser failure rate than individuals with multiple defects ${ }^{47}$. Those who had a prior surgery that penetrated the subchondral bone and marrow have a greater failure rate in autologous chondrocyte implantation (ACI) than those who have no history of surgery ${ }^{48}$. In a comparison of individuals who required multiple chondral surgeries, those who received ACI as a first line treatment had lesser failure rates and better International Knee Documentation Committee
2000 Subjective Knee Form (IKDC2000) scores compared to those who had microfracture as their first surgery. Despite a greater failure rate, however, the microfracture group still participated in the same amount of physical activity and at the same frequency and intensity as the ACI group ${ }^{49}$.

\section{Return to sport}

In a recent systematic review of outcomes after ACLR, $88 \%$ of athletes returned to sport, $65 \%$ returning to their pre-injury level, and 55\% returning to competitive play $^{50}$. Athletes who had not returned to sport 12 months after surgery were just as likely to be playing 39 months after surgery as those who had returned to play at 12 months $^{51}$. Self-reported function was different between those playing some sport and those who stopped all activity ${ }^{52}$. Five years after surgery, those who had not returned to sport have worse functional and self-report scores than those who had returned ${ }^{53}$.

Return to sport rates have been reported as high as $98 \%$ after meniscal surgery ${ }^{54}$. Even with concomitant grade III or IV articular surface lesions, $48 \%$ of individuals in their forties return to sport and $75 \%$ resume recreational activities ${ }^{55}$. In athletes under 40 , nearly a quarter of those after medial meniscectomies and over half of those after lateral meniscectomies had pain at the time of return to sport; however, pain and swelling were not related to the size of the meniscal resection. In a five-year follow-up study of individuals younger than 45 years old, less than $25 \%$ modified their level of athletic participation after partial meniscectomy ${ }^{55}$. However, at 14 years after meniscal surgery, $46 \%$ reduced their sporting activity and $6.5 \%$ changed occupation as a result of their knees ${ }^{56}$. Seventy-five percent of soccer players after isolated meniscectomy were still playing soccer five years after surgery compared to $52 \%$ of those who had combined meniscectomy and ACLR. By the 20 -year follow-up, $49 \%$ of the isolated meniscectomy group was still playing sports compared to $22 \%$ of meniscectomy+ACLR group ${ }^{57}$.

In recreational and amateur athletes, $66 \%$ return to sports in eight months after microfracture, with $67 \%$ of those eventually returning to a competition level. After 2-5 years however, $49 \%$ of athletes have reduced their level of play and $42 \%$ have poorer function $^{58}$. In professional sports, return-to-play after microfracture has been studied in the National Football League (NFL) and National Basketball Association (NBA). Seventy-six percent of NFL 
players $^{59}$ and NBA players ${ }^{60,61}$ returned to play after microfracture. For most NBA athletes who returned, minutes played per game, points per game, and steals per game decreased compared to pre-surgery. There is conflicting data concerning length of NBA career after microfracture, with some finding no difference ${ }^{61}$ and others finding a decreased likelihood (-LR of 8.15) of continued participation ${ }^{60}$. Average return-to-sport rates in an athletic population after matrix-induced autologous chondrocyte implantation (MACI) is $74 \%{ }^{62}$, osteochondral autologous transfer is $91 \%$, and osteochondral allograft transplantation is $88 \%{ }^{62,63}$. $\mathrm{ACI}$ is reported to allow the best longevity in sport, with $87 \%$ of patients after ACI able to maintain their ability to play at five years after surgery ${ }^{62}$.

\section{Long-term impact}

A history of knee injury, regardless of type, places an individual at a greater risk of subsequent injury. In a study of National Collegiate Athletic Association (NCAA) athletes, those with a history of knee surgery missed more days of sport, had a greater number of knee injuries, and received more magnetic resonance imaging (MRI) tests and surgeries than those athletes with no prior knee injury ${ }^{64}$. Former top-level male athletes with a history of knee injury have a nearly five-fold risk to develop $\mathrm{OA}^{65}$. Sports participation and history of ACL injury are both significant risk factors for the development of OA, but meniscal injury in combination with ACL injury may be one of the most potent combinations causing a ten-fold increase in risk compared to age-matched controls ${ }^{66,67}$.

Total knee arthroplasty and other reconstructive surgeries have advanced significantly in the last decade, allowing former athletes to remain active. However, at a rate of nearly 600,000 per year, with an expected increase to 3.5 million per year by $2030^{68}$, it is imperative that efforts are made to prevent the need for such surgical procedures.

\section{- Risk factors for re-injury or suboptimal performance upon return to activities}

In order to develop a system using rehabilitation indicators for profiling recovery after knee injury or surgery, an understanding of the non-modifiable and modifiable factors that can influence recovery or risk of re-injury is needed. A centralized portal that can track the longitudinal record of rehabilitation indicators can then be used as a means to define an athlete's recovery performance profile. Additionally, profiles can be utilized in establishing criteria to identify thresholds for safe return to sport. Furthermore, the profile can be used as a reference for any rehabilitation specialist interested in developing a similar recovery monitoring system.

\section{Patient demographics}

While patient demographics (e.g. age and sex) are non-modifiable factors, understanding their relationship to re-injury and function can guide clinicians in monitoring and counseling athletes appropriately. Younger athletes with knee injuries typically return more frequently and earlier to sports than older athletes $^{69,70}$. However, younger athletes (under the age of 25) are also more likely to suffer a second ACL injury after primary ACLR ${ }^{71-73}$.

Primary knee injury and subsequent $2^{\text {nd }}$ knee injury may be sex-specific. While the incidence of injury to the ACL is greater in men due to the greater exposure to sports, women have a relative risk of injury two to eight times greater than $\operatorname{men}^{74,75}$. However, a recent meta-analysis found no difference between men and women in the risk of patellar tendon graft rupture (Odds ratio (95\% confidence interval) $=0.76(0.29,2.09))$, hamstring graft rupture (Odds ratio $=0.86(0.53,1.39))$, or contralateral ACL rupture risk $(\text { Odds ratio }=0.58(0.29,1.17))^{76}$. Similarly, differences in patient-reported knee function do not appear to be sex-specific ${ }^{76}$, although women may return to less demanding activity levels after ACLR ${ }^{77,78}$.

\section{Physical impairments}

Range of motion (ROM) symmetry is unique to the individual; however, a knee extension loss of as little as $3^{\circ}$ is associated with poor post-surgical, patient-reported outcomes and task-specific activities ${ }^{79-81}$. Knee ROM asymmetries are also associated with degenerative joint changes ${ }^{79,81}$.

Muscle strength deficits are pervasive after knee injury and surgery ${ }^{82-85}$. Muscle strength limb-to-limb symmetry has been proposed as an important marker for readiness to return to unrestricted sport ${ }^{86-89}$. Early after knee injury, specifically ACL injury, quadriceps strength deficits range from $12-15 \%{ }^{90,91}$. Pre-operative quadriceps strength deficits are predictive of poor functional outcomes after ACLR ${ }^{92-94}$. The largest extent of quadriceps weakness occurs in the first six months after knee surgery ${ }^{92,95,96}$ and can be as great as $39-40 \% \%^{84,97-102}$. While hamstring strength deficits may be present after knee injury or surgery, these deficits 
do not influence clinical or functional outcomes ${ }^{103-105}$. However, the hamstrings-to-quadriceps ratio for torque production has been reported as a factor in primary ACL injury risk model ${ }^{106,107}$.

Quadriceps strength deficits can persist for months or years after any knee joint surgery, in spite of rehabilitation ${ }^{84,108}$. Consistent deficits in quadriceps strength have been found after surgery for the ACL, meniscus, and articular cartilage within the first year ${ }^{109}$, 2 years ${ }^{110,111}$, and up to 7 years ${ }^{112-114}$. Side-to-side deficits of more than $10 \%$ to $15 \%$ are considered significant and should be assessed throughout rehabilitation, and even into the second and third post-operative seasons $^{109-114}$.

Quadriceps strength asymmetry can also be reflected in other impairment measures. Quadriceps index (QI) is expressed as a percentage of the peak value of the quadriceps muscles on the involved side divided by the peak value of the quadriceps muscles on the uninvolved side. After ACLR, those with QI less than $85 \%$ have worse hop scores than those with a QI greater than $90 \%$ or controls. QI is a better predictor of hop test distance than graft type, presence of meniscal injury, knee pain, or knee symptoms ${ }^{115}$. After meniscectomy, particularly in middle-aged athletes, greater quadriceps strength is associated with better self-reported knee joint function on all five subscales of the Knee Injury and Osteoarthritis Outcome Score (KOOS) ${ }^{116}$. The KOOS is a knee-specific, patient-reported instrument for knee injuries that can lead to post-traumatic osteoarthritis. The form includes 42 items in five separately scored subscales: Pain (9 items); other symptoms ( 7 items); function in activities of daily living (ADLs; 17 items); function in sport and recreation (Sports; 5 items); and knee-related quality of life (QoL; 4 items) $)^{117}$. Individuals, two years after meniscectomy, continued to have a mean $6 \%$ asymmetry in strength and scored between 10 and 26 points worse on all five KOOS subscales compared to controls ${ }^{118}$.

Balance and postural deficits have been reported after knee injury, and in particular, after ACL injury and reconstruction. Various assessments have been used to evaluate risk of injury, current status, and the magnitude of improvement after an intervention ${ }^{119}$. While static postural tasks may provide useful clinical information, dynamic postural tasks may provide a more accurate representation of sporting activities. Some of these tasks may be simple, such as the Star Excursion Balance Test and Y-Balance tests ${ }^{119}$, while others require instrumented equipment ${ }^{120,121}$. Though some authors have tried quantifying limb symmetry for postural deficits, evidence is limited ${ }^{122}$.

\section{Performance-based measures}

Performance-based measures can be used to assess a combination of muscle strength, neuromuscular control, confidence in the injured limb, and ability to complete sport-specific activities ${ }^{123}$. Many drills and performance-based measures are double-legged tasks; however, the performance may mask persistent deficits in the injured lower extremity ${ }^{124}$. Therefore, single-legged tasks should be used after knee injuries to detect side-to-side differences, evaluate function, monitor progress of rehabilitation, and assess readiness for return to sports ${ }^{123,125-128}$. Single-legged hop tests measure distance, time, or height and typically involve multi-movement patterns (i.e. multi-planar directions, change of direction, acceleration-deceleration, etc.) that attempt to resemble athletic movements and may prepare patients for return to sporting activities ${ }^{129-132}$.

Side-to-side limb symmetry appears to have a critical role in the prevention of injury and return to sports after knee injuries. Varying performance standards (i.e. muscle strength or hop performance), ranging from $70 \%$ to $90 \%$ limb symmetry index (LSI), have been suggested as benchmarks for determining normal symmetry $86,125,132-134$. However, this range provides health care professionals no indication of an expected standard or a timeline on which they should be achieved.

Early after injury or surgery, individuals have poor single-legged hop LSI and substantial limb-to-limb differences ${ }^{83,123,129}$. Performance deficits on single-legged hop tests range from $5-35 \%$ with up to $47 \%$ of athletes not achieving normal limb symmetry (85-90\% LSI) six months after surgery ${ }^{83,85,129,135}$. By 12 months, the average LSI is greater than $90 \%$, and by 24 months, individuals are able to maintain normal hop symmetry ${ }^{83,85,136}$. LSI calculated from the cross-over hop for distance and 6-meter timed single-legged hop tests can also predict self-reported knee function at one year after ACLR. Poor LSI can predict poor knee function, while normal LSI can predict normal knee function ${ }^{137,138}$. Athletes six months after ACLR with an LSI less than $88 \%$ for the 6 -meter timed hop were five times more likely to rate themselves below normal ranges on the IKDC2000 one year after ACLR, whereas athletes with an LSI greater than $95 \%$ on the cross-over hop six months after ACLR were four times more likely to rate themselves within normal ranges on the IKDC2000 one year after ACLR ${ }^{138}$. Despite improvements in single-legged hop performance and symmetry in the first year after $\mathrm{ACLR}^{83,129}$, athletes two years after surgery have greater asymmetries in single-legged 
hop distances when compared to controls ${ }^{139}$. Poor LSI and large limb-to-limb differences prior to seven months after ACLR reconstruction can be a concern, as most post-surgical rehabilitation guidelines enable individuals to return to sports-specific activities between 4 to 6 months ${ }^{140,141}$. It is likely that sports-specific activities are more challenging than landing from a planned hop in a controlled environment, thus the deficits seen in single-legged hop performance may be magnified, potentially predisposing the ipsilateral or contralateral knee to injury. Because hop testing assesses current knee function, individuals with poor LSI may exhibit suboptimal performance on the playing field and may be placed at greater risk for injury ${ }^{88,142,143}$.

When comparing individuals after ACI and after microfracture, those after ACI have greater single hop asymmetry than those after microfracture six and twelve months after surgery. However, there is no difference between the groups in cross-over or 6-meter timed hop tests at six and twelve months. At 24 months, the microfracture groups had minimal asymmetry in hop performance (4-8\% asymmetry), while the ACI group had larger asymmetries (10-17\% asymmetry) on all three hop tests ${ }^{111}$.

\section{Symptoms}

Persistent symptoms, such as knee pain, joint swelling, stiffness, instability, or weakness, are common reasons many athletes cite for not returning to preinjury activity levels ${ }^{69}$. While pain may be a potential indicator of incomplete healing ${ }^{144}$, it typically resolves after knee injury and/or surgery. One year after ACLR, athletes who had not returned to sports reported an average pain intensity of $1.0 \pm 1.1$ out of $10(0=\text { no pain, } 10=\text { worst imaginable pain })^{145}$. Upon returning to sport after meniscectomy, pain and effusion can persist and should be monitored ${ }^{70}$. Pain can have a role in the decision-making process for allowing athletes to safely return to sports, but it should not be the sole determinant. Pain and effusion can be reliably monitored using a pain-monitoring scale ${ }^{146}$, soreness guidelines ${ }^{147}$, and the modified stroke test ${ }^{148}$.

Joint effusion is an over-accumulation of fluid within the joint capsule, indicating inflammation or irritation ${ }^{148}$. Joint effusion can be helpful in establishing a diagnosis, determining exercise progression, and monitoring progress. The presence of effusion can impair adjacent muscle function and alter knee motion $^{149,150}$. The presence of no effusion is also a significant contributor for the likelihood of return to sports one year after ACLR ${ }^{145}$. Monitoring of joint effusion can be practically, reliability, and clinically useful. The modified stroke test and effusion grading scale offers an objective means of measuring and assessing knee joint effusion ${ }^{148}$. This modified stroke test is performed by sweeping fluid proximally out of the medial sulcus of the knee, and then performing a distally directed sweep along the lateral knee and watching for a wave of fluid returning to the medial sulcus $^{148}$. An increase in effusion following treatment that does not return to baseline likely indicates that treatment progression was too aggressive. Furthermore, individuals should be able to demonstrate the ability to tolerate lower loading demands without pain or swelling before progressing to higher loads.

Symptomatic knee joint instability (giving way) is a hallmark of knee joint injury. Giving way episodes are usually described as buckling at the knee similar to the initial injury. While the magnitude of passive ligament instability is poorly associated with functional ability in ACL-deficient athletes ${ }^{151-153}$, dynamic knee stability may be more relevant. Subsequently, the absence of episodes of knee instability was a significant contributor (Wilks' $\lambda=0.357$ ) for the likelihood of return to sports one year after ACLR ${ }^{145}$. Recurrent episodes of instability may be an indicator of undiagnosed concomitant injuries (other ligamentous structures, meniscus) and can potentially increase the likelihood of further joint damage ${ }^{25}$.

\section{Gait asymmetry}

While the measurement of movement using motion capture is not considered a typical rehabilitation indicator, it does provide additional insight on the ubiquity of asymmetries seen after knee injury and surgery. Side-to-side asymmetrical movement patterns after knee injury are common and can persist for months or years after injury or surgery ${ }^{154}$. Additionally, these altered movement patterns are not limited to the index knee. Neuromuscular adaptations are present in the hip and ankle and contralateral limb after knee injury and surgery as well as during gait and higher-demand tasks, such as jumping ${ }^{154-157}$. Underlying neuromuscular imbalances on the operated and non-operated limbs at the time of return to sport clearance are highly predictive of $2^{\text {nd }}$ ACL injury ${ }^{158}$.

Even two years after ACLR, Roewer et al ${ }^{108}$ found that the involved limb had smaller knee excursion and internal knee extension moments compared to the uninvolved limb at weight acceptance. Gait asymmetries after ACLR are associated with poor 
quadriceps strength and functional performance. At peak knee flexion, those with a QI less than 90\% have a smaller knee flexion angle and significantly decreased internal knee extension moment compared to controls $^{159}$. QI alone accounts for more than a quarter of variance in angle at peak knee flexion, and QI and KOS-ADLS accounts for $60 \%$ of variance in internal knee extension moment ${ }^{159}$. Broadening the criteria to include QI, single-legged hop LSI, KOS-ADLS, and GRS, those who scored less than $90 \%$ on any one of these measures had greater knee kinematic and kinetic asymmetries than those who scored greater than $90 \%$ on all criteria and had clinically significant limb-to-limb asymmetry in hip flexion at peak knee flexion ${ }^{160}$

In higher-risk tasks such as jumping, women two years after ACLR demonstrate limb-to-limb asymmetries. Higher vertical ground reaction force and loading rate is seen on the uninvolved limb during landing compared to both the involved limb and controls $^{161}$. During takeoff, women also show lower force generation on the involved side compared to the uninvolved side ${ }^{161}$. Both men and women after ACLR have smaller internal knee extension moments on the involved limb during lateral step-down and vertical jump take-off and landing when compared to the uninvolved limb and to controls ${ }^{162}$. The results of these studies and similar research highlight the need to resolve impairments and restore functional limb symmetry after ACLR.

Gait asymmetries have been noted following meniscal surgery. Smaller peak knee flexion angles and lower peak external moments in the sagittal plane and larger knee adduction moments have been observed in the involved limb compared to the uninvolved limb after partial meniscectomy and compared to controls ${ }^{163}$. Asymmetry may be worse in individuals with weaker quadriceps after partial meniscectomy. Increased average and peak external knee adduction moments throughout stance phase have been observed in patients after meniscectomy with weaker quadriceps compared to those patients after meniscectomy with normal strength and controls ${ }^{164}$. Bulgheroni et al. ${ }^{165}$ found that those after medial meniscectomy had decreased external hip extension moment during all phases of gait and increased external knee flexion moment at loading response, push off, and throughout swing. They also had increased hip and knee flexion and increased ankle dorsiflexion in late swing phase ${ }^{165}$.

After ACI surgery, aberrant movement patterns are present, specifically reduced knee motion during weight acceptance and decreased external sagittal plane moments. These aberrant patterns can persist for months ${ }^{157,166}$, and alter joint loading ${ }^{167-169}$. Gait deviations may promote further cartilage damage through reduced shock absorption and increased joint loading ${ }^{170,171}$, predisposing the knee to degenerative changes ${ }^{167,172}$.

\section{Patient-reported outcomes}

Patient-reported outcome (PRO) measures are self-report questionnaires that measure an individual's perception of daily life and physical activity ${ }^{173,174}$. PROs show a greater relationship to on patient satisfaction than standard clinical measures ${ }^{175}$. PROs specific to the knee joint contain items to assess symptoms (i.e. pain, swelling, giving ways, etc.) and activity limitations (i.e. ambulation, stair climbing, running, etc.) $)^{176}$. PROs are clinically useful in comparing the results of interventions on patient perspective after injury ${ }^{175,177}$. Performance-based measures capture different domains of function than PROs ${ }^{125,178}$. Performance-based measures assess the actual functional ability of an athlete, whereas, PROs assess the perceived ability of aspects considered important by patients with knee problems, ranging from stair climbing to running and jumping. Therefore, a combination of outcome measures is likely necessary to provide a comprehensive evaluation of functional success ${ }^{178,179}$.

Knee performance and self-reported function generally improve over the first year after ACLR ${ }^{83}$. By six months after surgery, almost half of individuals score greater than $90 \%$ on Knee Outcome Survey-Activities of Daily Living Scale (KOS-ADLS) and Global Rating Scale of Perceived Function (GRS), and 78\% have achieved these scores by 12 months ${ }^{180}$. Poor self-report on outcome measures after ACLR are associated with chondral injury, previous surgery, return to sport, and poor radiological grade in ipsilateral medial compartment ${ }^{181}$. ACLR revision and extension deficits at 3 months are also predictors of poor long-term, patient-reported outcomes ${ }^{17,182}$.

The various surgical techniques for articular cartilage defects vary in their self-reported outcomes. Pooled data indicates that $67 \%$ of individuals report normal IKDC 2000 one year after microfracture, and $80 \%$ of individuals have significant increases from pre-surgery in Lysholm, Tegner, and KOOS sports subscale scores $^{183}$. While these patients have made significant improvements in their self-reported function, a large proportion of them continue to report function below normal levels. Four years after microfracture, the 
KOOS-ADL subscale, Marx Activity Rating Scale, and Tegner Score decreased in $47 \%$ of athletes, but despite this decrease in self-report, $44 \%$ were still able to regularly participate in pivoting sports, and $57 \%$ of those at their pre-operative level ${ }^{184}$. In a 15 -year longitudinal study, IKDC2000, Lysholm, and Tegner scores decreased over the course of the study; however, they were still better at 15 years after surgery than at baseline before surgery ${ }^{185}$. After osteochondral allograft transplantation for large chondral or osteochondral defects, athletes who returned to sport had better IKDC2000, KOOS, and Marx Activity Rating Scale scores $^{186}$. Kreuz et al. ${ }^{187}$ compared inactive/rarely active individuals to active individuals after autologous chondrocyte implantation (ACI). Pre-operatively, there were no differences between groups, but at 6 , 12 , and 36 months after surgery, the active group had significantly better International Cartilage Repair Society (ICRS) and Cincinnati Knee Rating System scores compared to the inactive/rarely active group $^{187}$. All five KOOS subscales increase over the course of the first one to two years after MACI and improvements are maintained five years after surgery. Improvements in IKDC2000, modified Cincinnati Knee Rating System, Tegner, Lysholm, and Short Form-36 (SF36) scores as well as knee extension range of motion continue to gradually improve over the first five years following MACI ${ }^{188,189}$.

\section{Decision-making considerations and the importance of symmetry}

Determining when a patient is performing well enough to safely and effectively return to play or activity is a complex decision that must take into account the risk factors for re-injury or poor function. Meeuwisse et al. ${ }^{190}$ has proposed a model that integrates the risk of the athlete within a dynamic sporting environment, considering both intrinsic and extrinsic factors that lead to different injury events and their variability. The remainder of this commentary outlines a proactive decision-making model that measures changes in intrinsic and extrinsic factors and can be predictive, preventative, personalized, and participatory. This model can provide rehabilitation specialists crucial data pertinent to patients' current knee function, their progress during rehabilitation, the necessity for additional rehabilitation, and their readiness to return to sporting activities.

Creighton et al. ${ }^{144}$ has proposed a decision-based return-to-play model that involves three steps. Step 1 is an evaluation of health status that focuses on type and severity of the injury, clinical or physical signs and symptoms, functional performance, and psychological state. Step 2 evaluates the risk of sport participation from the type of sport, competition level, or position played to the use of protective equipment. Step 3 or decision-modification step frequently involves nonmedical factors, such as timing and season of the sport, external pressures to compete, and legal implications. For this review, we will focus on the components highlighted in Step 1 (Evaluation of Health Status) as these are likely the medical/clinical risk factors that can be modified by the clinician. The medical/clinical variables that are frequently associated with return to activities or sports include demographic factors, physical impairments, activity limitations, psychological factors, and patient-reported scores $^{145,191,192}$.

Limb-to-limb symmetry or limb symmetry indexes are used after injury or surgery as important indicators of physical impairments, activity limitations, and function. They are also used to monitor the progress of rehabilitation and to assess readiness for return to activity or sports, therefore they should be benchmarked against performance standards. Unfortunately, no empirically based benchmarks or expert consensus benchmarks exist regarding performance standards at specific time points after knee injury. Development of standards can provide relevant information about patient performance and can help to determine if additional interventions are needed to achieve this level.

\section{Profiling and monitoring recovery of athletes after knee injury or surgery}

Injury to the meniscus, cartilage, or ligaments of the knee results in a fairly consistent clinical presentation and an increase in the risk for post-traumatic osteoarthritis. Creating a profile of these individuals is important to promote a comprehensive evaluation of the patient to eliminate basic impairments after surgery and to facilitate a safe and effective return to sport process that minimizes the risk for second injury. Additionally, using a consistent set of measures at consistent time frames allows for assessment of trends in patient outcomes.

One of the challenges in developing an injury risk profile for post-injury or post-operative management has been to select appropriate clinical or field tests that can detect side-to-side asymmetries, assess global knee function, and determine a patient's readiness to 
return to sport. Batteries of tests have been developed to predict the risk for musculoskeletal injuries ${ }^{193}$, classify individuals early after ACL injury ${ }^{194}$, and identify important limb asymmetries after ACL injury and reconstruction ${ }^{195,196}$. One battery of performance-based tests was moderately correlated with the IKDC2000 and could discriminate between the operated and non-operated limbs of patients after ACLR ${ }^{197}$. However, very few studies incorporate performance-based and patient-reported outcomes into the clinical decision making to fully evaluate a patient's knee function ${ }^{12,198}$. Clinical impairments, performance-based measures, and patient-reported outcomes capture different aspects of overall knee performance and are important indicators of function ${ }^{125,199-201}$. Therefore, a battery of tests utilizing performance-based and patient-reported outcomes can provide clinically relevant data applicable to current knee function, progress throughout rehabilitation and the necessity for additional targeted interventions, and their readiness to return to sporting activities.

\section{Sports knee injury performance profile}

While many different tests and measures are available for functional testing ${ }^{202,203}$, the Sports Knee Injury Performance Profile (SKIPP) is a battery of tests and measures consisting of thigh muscle strength testing, single-legged hop testing, and patient-reported outcome measures. The data included in the SKIPP have not been independently validated; however, that process is ongoing. Prior to performing the battery of tests, athletes should exhibit a minimum criteria of little to no joint effusion, full active range of motion, normal gait pattern upon visual observation, and ability to hop in place on a single leg without pain.

Quadriceps and hamstring strength can be tested using isokinetic peak torque or maximal voluntary isometric contraction (MVIC). Peak force or torque values achieved during strength testing bilaterally are recorded and used to calculate a quadriceps index (QI) or hamstrings index (HI). QI is expressed as a percentage of the peak value of the quadriceps muscles on the involved side divided by the peak value of the quadriceps muscles on the uninvolved side. Hamstrings index is expressed similarly.

Following quadriceps strength testing, participants perform single-legged hop tests. Four single-legged hop tests are used in our clinic: single hop for distance (single hop); cross-over hop for distance (cross-over hop); triple hop for distance (triple hop); and 6-meter timed hop ${ }^{132}$. A hop score for each test is calculated as the average of the two recorded trials. For the single hop, cross-over hop, and triple hop LSI, these LSIs are expressed as the percentage performance on the involved side compared to the uninvolved side. For the 6-meter timed hop, the 6-meter timed hop LSI is expressed as the percentage performance of the uninvolved side compared to the involved side, given that faster times (low numbers) are better for this hop test.

Following hop testing, participants complete self-report questionnaires: KOS-ADLS, GRS, IKDC2000, and the ACL-Return to Sports after Injury (ACL-RSI). The KOS-ADLS is a 14-item patient-reported outcome of symptoms and functional limitations of the knee during $\mathrm{ADLs}^{204}$. Patients must be able to perform their ADLs at a normal level prior to attempting a return to sports, otherwise they are likely to report having difficulty with sporting activities and placing themselves at risk for subpar performance and re-injury. The GRS asks participants to rate their current knee function on a scale from 0 to 100 , with 0 being the inability to perform any activity and 100 being the level of knee function prior to the injury, including sports ${ }^{204,205}$. The IKDC2000 is a frequently used assessment of function ${ }^{206}$ and can differentiate between individuals with low versus high knee function ${ }^{207}$. The published IKDC2000 normative dataset ${ }^{207}$ provides a reference standard for normal knee function (Table 1) 137,138. $^{\text {. }}$

ACL-RSI is a 12-item patient-reported outcome of emotions, confidence in performance, and risk appraisal after ACLR. It can discriminate psychological differences between athletes who returned to sports and those who did not return to sports ${ }^{208,209}$. The data collected from this battery of tests can be used as a set of performance indicators that can detect side-to-side asymmetries, assess global knee function, and determine a patient's readiness to return to sport. This permits the clinician to visualize and appreciate the dynamic profile of the injured athlete and aids the clinician in decision making about readiness to return to activity and in the formulation of targeted, personalized interventions to overcome performance barriers and optimize sports performance.

\section{Recommendations for return to activity criteria}

The rehabilitation indicators from the SKIPP can be used to determine readiness to return to activities or sports - an improvement over the current timebased rehabilitation protocols. No functional test battery for return to sports has been validated to identify cutoffs which reduce the risk of injury to this 
point. Despite impairments, activity restrictions, poor self-report scores, and limb-to-limb asymmetries, many post-surgical rehabilitation guidelines permit individuals to return to sports-specific activities between three to nine months after surgery, depending on the lesion and surgical technique. However, the use of a time-based approach does not adequately account for these deficits ${ }^{210}$. A majority of clinicians continue to use a time-based approach and passive stability measures to allow return to play after ACLR ${ }^{211}$. A recent systematic review noted that only one or two criteria (muscle strength and single-leg hop test) have been used as objective measures for resuming play in the majority of studies ${ }^{12}$. In studies that did use objective measurable criteria, none provided cutoffs for their criteria that have been validated for normal knee function, successful return to activities, or re-injury rates $^{12,211,212}$. Objective, measurable criteria are critical to ensure that athletes are fully rehabilitated and their knees are ready to meet the demands of their activities or sport.

Recently, two paradigms of return to activity criteria have been proposed by the European Board of Sports Rehabilitation and the University of Delaware as recommendations to clear athletes to begin a progressive and systematic approach to activities and sports ${ }^{89,194}$. The European Board of Sports Rehabilitation have developed a set of criteria using performance-based measures prior to athletes returning to activities or sport after $\mathrm{ACLR}^{89}$. Their recommendations are categorized based on type of activity: activities that are pivoting, contact, or competitive and activities that are non-pivoting, non-contact, or recreational. For the pivoting/contact/competitive group, they recommend that involved limb knee extensor and knee flexor muscle strength performance be equal to $100 \%$ of the uninvolved limb (100\% LSI) and that involved limb hop performance on two maximum hop tests (e.g. single hop for distance, vertical hop, etc.) and one endurable hop test (e.g. triple hop, stair hop, side hop, etc.) be at least $90 \%$ of the uninvolved limb ( $90 \%$ LSI). For the non-pivoting/non-contact/recreational group, they recommend that involved limb knee extensor and knee flexor muscle strength performance be at least $90 \%$ of the uninvolved limb (90\% LSI) and that involved limb hop performance on one maximum or one endurable hop tests be at least $90 \%$ of the uninvolved limb (90\% LSI). These recommendations take into account both knee extensor and knee flexor strength and hop performance; however, one limitation of these recommendations is the omission of the use of
PROs as criteria for return to activity. As stated before, PROs do not correlate highly with performance-based measures, but capture different aspects of knee function. It has been suggested that both performance-based measures and PROs are needed to fully characterize an athlete's knee function ${ }^{83}$.

The University of Delaware has instituted return to activity criteria and used them for over 15 years ${ }^{194}$. Functional testing to determine return to activity criteria includes performance-based and PRO measures from the SKIPP. These criteria are sensitive to knee functional changes over time and can provide clinicians with clinically relevant information about patients' responses to different therapeutic interventions ${ }^{83}$. To pass return to activity, participants were required to achieve $90 \%$ or greater on each of the functional tests and measures from the battery of tests (QI, 4 hop LSIs, KOS-ADLS, and GRS) (Figure 1) $)^{86,194}$.

Work from our laboratory has demonstrated that the University of Delaware Return to Activity Criteria (RTAC) can accurately discern between two differently functioning cohorts of athletes after ACL injury or reconstruction. The RTAC demonstrated that participants who successfully returned to high-level activity after non-operative management of an ACL injury had less than a $10 \%$ deficit on their baseline scores on average ${ }^{194}$. Athletes who fail our RTAC six months after ACLR exhibit greater limb-to-limb movement asymmetries than those who pass our RTAC $^{69}$. Six and 12 months after ACL surgery, poor IKDC2000 function scores were reasonably indicative of RTAC test battery failure, whereas normal IKDC2000 scores were not predictive of passing scores on the RTAC test battery ${ }^{138}$. Additionally, those athletes who demonstrated limb-to-limb movement symmetry and self-reported knee function 6 months after ACLR are more likely to return to their preinjury activity level 12 months after ACLR ${ }^{213}$. The results of these studies highlight the importance of using performance-based and patient-reported measures to identify participants with poor knee function and limb-to-limb movement asymmetry before clearing them to return to high-demand activities. The use of these RTAC can be used early after any knee injury or surgery to assess residual deficits that needed to be resolved prior to attempting a return to high-risk sporting activities.

The validation of the RTAC to determine safe and optimal return to activities or to predict future injuries is ongoing. Several clinical variables have been identified with returning to sports ${ }^{145,191,192,198}$; 


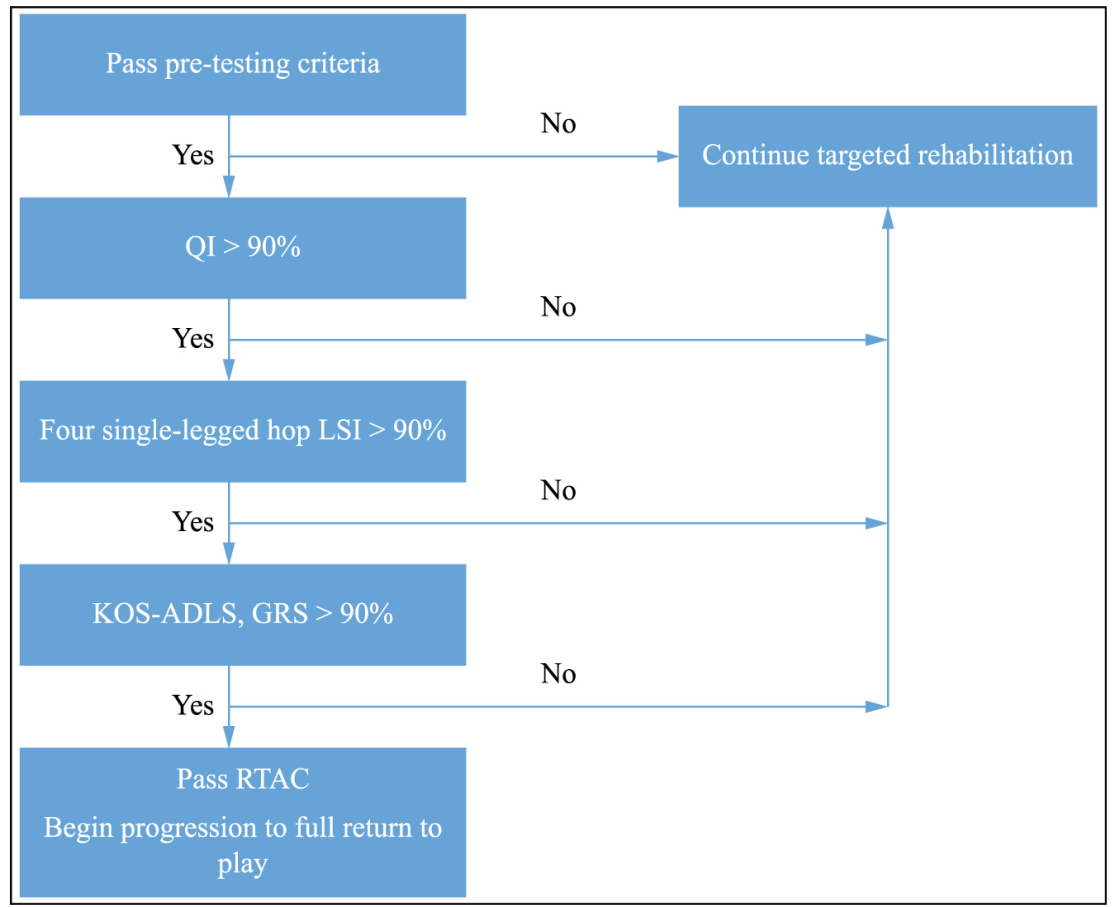

Figure 1. Algorithm for passing return to activity criteria.

Table 1. IKDC2000 cutoff scores for normal ranges for age- and sex-specific groups ${ }^{215}$.

\begin{tabular}{cc}
\hline Age Group & Normal IKDC2000 cutoff \\
$18-24$ & Men: 89.7 \\
& Women: 83.9 \\
$25-34$ & Men: 86.2 \\
$35-50$ & Women: 82.8 \\
& Men: 85.1 \\
$51-65$ & Women: 78.5 \\
& Men: 74.7 \\
& Women: 69.0 \\
\hline
\end{tabular}

however, none have been studied to predict future injury ${ }^{154,214}$. Further research is needed to identify if the tests in the SKIPP and the criteria for the RTAC can accurately identify which athletes are more likely to return to activities and which ones are more likely to sustain a second injury.

\section{Conclusions}

Knee injuries are common in sports. Despite the advances made in surgical techniques and rehabilitation interventions, return to sport rates are poorer than previously thought, and the risk of re-injury or failure after knee surgery is greater than expected. The development of the Sports Knee
Injury Performance Profile allows the clinician to consistently monitor knee function, track progress throughout rehabilitation, and incorporate targeted, personalized interventions to achieve optimal sports performance and function while potentially reducing the risk of re-injury or failure. The implementation of established return to activity criteria provides a platform to ensure that athletes are fully rehabilitated and can begin to introduce loads needed to participate in their sport or activities. Consistent implementation of this profile will allow clinicians to track individual patient progress and to assess trends in their patients over time.

\section{References}

1. Jacobs JJ, Andersson GB, Bell J, Weinstein SL, Dormans JP, Gnatz SM, et al. The burden of musculoskeletal diseases in the United States. Rosemont: American Academy of Orthopaedic Surgeons; 2008.

2. Yelin EH. Medical expenditures panel survey 1996-2006. Rockville: Agency for Healthcare Research and Quality; 1996.

3. Gage BE, McIlvain NM, Collins CL, Fields SK, Comstock RD. Epidemiology of 6.6 million knee injuries presenting to United States emergency departments from 1999 through 2008. Acad Emerg Med. 2012;19(4):378-85. http://dx.doi org/10.1111/j.1553-2712.2012.01315.x. PMid:22506941. 
4. Ingram JG, Fields SK, Yard EE, Comstock RD. Epidemiology of knee injuries among boys and girls in US high school athletics. Am J Sports Med. 2008;36(6):1116-22. http:// dx.doi.org/10.1177/0363546508314400. PMid:18375784.

5. Powell JW, Barber-Foss KD. Injury patterns in selected high school sports: a review of the 1995-1997 seasons. J Athl Train. 1999;34(3):277-84. PMid:16558577.

6. Buckwalter JA, Saltzman C, Brown T. The impact of osteoarthritis: implications for research. Clin Orthop Relat Res. 2004;427(Suppl):S6-15. http://dx.doi.org/10.1097/01. blo.0000143938.30681.9d. PMid:15480076.

7. Griffin LY, Agel J, Albohm MJ, Arendt EA, Dick RW, Garrett WE, et al. Noncontact anterior cruciate ligament injuries: risk factors and prevention strategies. J Am Acad Orthop Surg. 2000;8(3):141-50. PMid:10874221.

8. Kim S, Bosque J, Meehan JP, Jamali A, Marder R. Increase in outpatient knee arthroscopy in the United States: a comparison of National Surveys of Ambulatory Surgery, 1996 and 2006. J Bone Joint Surg Am. 2011;93(11):994-1000. http://dx.doi.org/10.2106/JBJS.I.01618. PMid:21531866.

9. Murphy L, Schwartz TA, Helmick CG, Renner JB, Tudor $\mathrm{G}$, Koch G, et al. Lifetime risk of symptomatic knee osteoarthritis. Arthritis Rheum. 2008;59(9):1207-13. http:// dx.doi.org/10.1002/art.24021. PMid:18759314.

10. Kern D, Zlatkin MB, Dalinka MK. Occupational and posttraumatic arthritis. Radiol Clin North Am. 1988;26(6):134958. PMid:3051099.

11. Brown TD, Johnston RC, Saltzman CL, Marsh JL, Buckwalter JA. Posttraumatic osteoarthritis: a first estimate of incidence, prevalence, and burden of disease. J Orthop Trauma. 2006;20(10):739-44. http://dx.doi.org/10.1097/01. bot.0000246468.80635.ef. PMid:17106388.

12. Barber-Westin SD, Noyes FR. Objective criteria for return to athletics after anterior cruciate ligament reconstruction and subsequent reinjury rates: a systematic review. Phys Sportsmed. 2011;39(3):100-10. http://dx.doi.org/10.3810/ psm.2011.09.1926. PMid:22030946.

13. Griffin LY, Agel J, Albohm MJ, Arendt EA, Dick RW, Garrett WE, et al. Noncontact anterior cruciate ligament injuries: risk factors and prevention strategies. J Am Acad Orthop Surg. 2000;8(3):141-50. PMid:10874221.

14. Frobell RB, Lohmander LS, Roos HP. Acute rotational trauma to the knee: poor agreement between clinical assessment and magnetic resonance imaging findings. Scand J Med Sci Sports. 2007;17(2):109-14. PMid:17394470.

15. Frobell RB, Roos HP, Roos EM, Hellio Le Graverand MP, Buck R, Tamez-Pena J, et al. The acutely ACL injured knee assessed by MRI: are large volume traumatic bone marrow lesions a sign of severe compression injury? Osteoarthritis Cartilage. 2008;16(7):829-36. http://dx.doi. org/10.1016/j.joca.2007.11.003. PMid:18206394.

16. Røtterud JH, Sivertsen EA, Forssblad M, Engebretsen L, Arøen A. Effect of meniscal and focal cartilage lesions on patient-reported outcome after anterior cruciate ligament reconstruction: a nationwide cohort study from Norway and Sweden of 8476 patients with 2-year follow-up. Am J Sports Med. 2013;41(3):535-43. http://dx.doi. org/10.1177/0363546512473571. PMid:23371474.
17. Cox CL, Huston LJ, Dunn WR, Reinke EK, Nwosu SK, Parker RD, et al. Are articular cartilage lesions and meniscus tears predictive of IKDC, KOOS, and Marx activity level outcomes after anterior cruciate ligament reconstruction? A 6-year multicenter cohort study. Am J Sports Med. 2014;42(5):1058-67. http://dx.doi. org/10.1177/0363546514525910. PMid:24647881.

18. Lewis DW, Chan D, Fisher O, Lechford R, Mintowt-Czyz WJ, Lewis MWD. Incidence of meniscal and chondral injuries at the time of ACL reconstruction, and their relationship with outcome at 2 years. J Bone Joint Surg Br. 2012;94-B(Supp IX):41.

19. Swenson DM, Collins CL, Best TM, Flanigan DC, Fields SK, Comstock RD. Epidemiology of knee injuries among U.S. high school athletes, 2005/2006-2010/2011. Med Sci Sports Exerc. 2013;45(3):462-9. http://dx.doi.org/10.1249/ MSS.0b013e318277acca. PMid:23059869.

20. Abrams GD, Frank RM, Gupta AK, Harris JD, McCormick FM, Cole BJ. Trends in meniscus repair and meniscectomy in the United States, 2005-2011. Am J Sports Med. 2013;41(10):2333-9. http://dx.doi.org/10.1177/0363546513495641. PMid:23863849.

21. Arøen A, Løken S, Heir S, Alvik E, Ekeland A, Granlund OG, et al. Articular cartilage lesions in 993 consecutive knee arthroscopies. Am J Sports Med. 2004;32(1):211-5. http:// dx.doi.org/10.1177/0363546503259345. PMid:14754746.

22. Curl WW, Krome J, Gordon ES, Rushing J, Smith BP, Poehling GG. Cartilage injuries: a review of 31,516 knee arthroscopies. Arthroscopy. 1997;13(4):456-60. http://dx.doi. org/10.1016/S0749-8063(97)90124-9. PMid:9276052.

23. Flanigan DC, Harris JD, Trinh TQ, Siston RA, Brophy RH. Prevalence of chondral defects in athletes' knees: a systematic review. Med Sci Sports Exerc. 2010;42(10):1795801. http://dx.doi.org/10.1249/MSS.0b013e3181d9eea0. PMid:20216470.

24. Piasecki DP, Spindler KP, Warren TA, Andrish JT, Parker $\mathrm{RD}$. Intraarticular injuries associated with anterior cruciate ligament tear: findings at ligament reconstruction in high school and recreational athletes. An analysis of sexbased differences. Am J Sports Med. 2003;31(4):601-5. PMid:12860552.

25. Logerstedt DS, Snyder-Mackler L, Ritter RC, Axe MJ, Godges J. Knee pain and mobility impairments: meniscal and articular cartilage lesions. J Orthop Sports Phys Ther. 2010;40(6):A1-35. http://dx.doi.org/10.2519/jospt.2010.0304. PMid:20511698.

26. Hjelle K, Solheim E, Strand T, Muri R, Brittberg M. Articular cartilage defects in 1,000 knee arthroscopies. Arthroscopy. 2002;18(7):730-4. http://dx.doi.org/10.1053/ jars.2002.32839. PMid:12209430.

27. Curl WW, Krome J, Gordon ES, Rushing J, Smith BP, Poehling GG. Cartilage injuries: a review of 31,516 knee arthroscopies. Arthroscopy. 1997;13(4):456-60. http://dx.doi. org/10.1016/S0749-8063(97)90124-9. PMid:9276052.

28. Arøen A, Løken S, Heir S, Alvik E, Ekeland A, Granlund OG, et al. Articular cartilage lesions in 993 consecutive knee arthroscopies. Am J Sports Med. 2004;32(1):211-5. http:// dx.doi.org/10.1177/0363546503259345. PMid:14754746.

29. Widuchowski W, Widuchowski J, Trzaska T. Articular cartilage defects: study of 25,124 knee arthroscopies. 
Knee. 2007;14(3):177-82. http://dx.doi.org/10.1016/j. knee.2007.02.001. PMid:17428666.

30. Johnson-Nurse C, Dandy DJ. Fracture-separation of articular cartilage in the adult knee. J Bone Joint Surg Br. 1985;67(1):42-3. PMid:3968141.

31. Keays SL, Newcombe PA, Bullock-Saxton JE, Bullock MI, Keays AC. Factors involved in the development of osteoarthritis after anterior cruciate ligament surgery. Am J Sports Med. 2010;38(3):455-63. http://dx.doi. org/10.1177/0363546509350914. PMid:20051501.

32. Li RT, Lorenz S, Xu Y, Harner CD, Fu FH, Irrgang JJ. Predictors of radiographic knee osteoarthritis after anterior cruciate ligament reconstruction. Am J Sports Med. 2011;39(12):2595603. http://dx.doi.org/10.1177/0363546511424720. PMid:22021585.

33. Paterno MV, Rauh MJ, Schmitt LC, Ford KR, Hewett TE. Incidence of contralateral and ipsilateral anterior cruciate ligament (ACL) injury after primary ACL reconstruction and return to sport. Clin J Sport Med. 2012;22(2):11621. http://dx.doi.org/10.1097/JSM.0b013e318246ef9e. PMid:22343967.

34. Lind M, Menhert F, Pedersen AB. The first results from the Danish ACL reconstruction registry: epidemiologic and 2 year follow-up results from 5,818 knee ligament reconstructions. Knee Surg Sports Traumatol Arthrosc. 2009;17(2):117-24. http://dx.doi.org/10.1007/s00167-0080654-3. PMid:18974970.

35. Ellis HB, Matheny LM, Briggs KK, Pennock AT, Steadman JR. Outcomes and revision rate after bone-patellar tendonbone allograft versus autograft anterior cruciate ligament reconstruction in patients aged 18 years or younger with closed physes. Arthroscopy. 2012;28(12):1819-25. http:// dx.doi.org/10.1016/j.arthro.2012.06.016. PMid:23102671.

36. Leys T, Salmon L, Waller A, Linklater J, Pinczewski L. Clinical results and risk factors for reinjury 15 years after anterior cruciate ligament reconstruction: a prospective study of hamstring and patellar tendon grafts. Am J Sports Med. 2012;40(3):595-605. http://dx.doi. org/10.1177/0363546511430375. PMid:22184280.

37. Webster KE, Feller JA, Leigh WB, Richmond AK. Younger patients are at increased risk for graft rupture and contralateral injury after anterior cruciate ligament reconstruction. Am J Sports Med. 2014;42(3):641-7. http:// dx.doi.org/10.1177/0363546513517540. PMid:24451111.

38. Hui C, Salmon LJ, Kok A, Maeno S, Linklater J, Pinczewski LA. Fifteen-year outcome of endoscopic anterior cruciate ligament reconstruction with patellar tendon autograft for "isolated" anterior cruciate ligament tear. Am J Sports Med. 2011;39(1):89-98. http://dx.doi.org/10.1177/0363546510379975. PMid:20962336.

39. Paterno MV, Rauh MJ, Schmitt LC, Ford KR, Hewett TE. Incidence of Second ACL Injuries 2 Years After Primary ACL Reconstruction and Return to Sport. Am J Sports Med. 2014;42(7):1567-73. http://dx.doi. org/10.1177/0363546514530088. PMid:24753238.

40. Shelbourne KD, Gray T, Haro M. Incidence of subsequent injury to either knee within 5 years after anterior cruciate ligament reconstruction with patellar tendon autograft. Am J Sports Med. 2009;37(2):246-51. http://dx.doi. org/10.1177/0363546508325665. PMid:19109531.
41. Kamath GV, Murphy T, Creighton RA, Viradia N, Taft TN, Spang JT. Anterior Cruciate Ligament Injury, Return to Play, and Reinjury in the Elite Collegiate Athlete: Analysis of an NCAA Division I Cohort. Am J Sports Med. 2014;42(7):1638-43. http://dx.doi. org/10.1177/0363546514524164. PMid:24981340.

42. Nepple JJ, Dunn WR, Wright RW. Meniscal repair outcomes at greater than five years: a systematic literature review and meta-analysis. J Bone Joint Surg Am. 2012;94(24):2222-7. http://dx.doi.org/10.2106/JBJS.K.01584. PMid:23318612.

43. Lyman S, Hidaka C, Valdez AS, Hetsroni I, Pan TJ, Do $\mathrm{H}$, et al. Risk factors for meniscectomy after meniscal repair. Am J Sports Med. 2013;41(12):2772-8. http://dx.doi. org/10.1177/0363546513503444. PMid:24036573.

44. Tengrootenhuysen M, Meermans G, Pittoors K, van Riet R, Victor J. Long-term outcome after meniscal repair. Knee Surg Sports Traumatol Arthrosc. 2011;19(2):236-41. http:// dx.doi.org/10.1007/s00167-010-1286-y. PMid:20953762.

45. Vanderhave KL, Moravek JE, Sekiya JK, Wojtys EM. Meniscus tears in the young athlete: results of arthroscopic repair. J Pediatr Orthop. 2011;31(5):496-500. http://dx.doi. org/10.1097/BPO.0b013e31821ffb8d. PMid:21654455.

46. Paxton ES, Stock MV, Brophy RH. Meniscal repair versus partial meniscectomy: a systematic review comparing reoperation rates and clinical outcomes. Arthroscopy. 2011;27(9):1275-88. http://dx.doi.org/10.1016/j. arthro.2011.03.088. PMid:21820843.

47. Solheim E, Øyen J, Hegna J, Austgulen OK, Harlem T, Strand T. Microfracture treatment of single or multiple articular cartilage defects of the knee: a 5-year median follow-up of 110 patients. Knee Surg Sports Traumatol Arthrosc. 2010;18(4):504-8. http://dx.doi.org/10.1007/ s00167-009-0974-y. PMid:19865812.

48. Minas T, Gomoll AH, Rosenberger R, Royce RO, Bryant $T$. Increased failure rate of autologous chondrocyte implantation after previous treatment with marrow stimulation techniques. Am J Sports Med. 2009;37(5):902-8. http:/ dx.doi.org/10.1177/0363546508330137. PMid:19261905.

49. Pestka JM, Bode G, Salzmann G, Südkamp NP, Niemeyer P. Clinical outcome of autologous chondrocyte implantation for failed microfracture treatment of full-thickness cartilage defects of the knee joint. Am J Sports Med. 2012;40(2):325-31. http://dx.doi.org/10.1177/0363546511425651. PMid:22056348.

50. Ardern CL, Taylor NF, Feller JA, Webster KE. Fifty-five per cent return to competitive sport following anterior cruciate ligament reconstruction surgery: an updated systematic review and meta-analysis including aspects of physical functioning and contextual factors. Br J Sports Med. 2014;48(21):1543-52. http://dx.doi.org/10.1136/ bjsports-2013-093398. PMid:25157180.

51. Ardern CL, Taylor NF, Feller JA, Webster KE. Return-to-sport outcomes at 2 to 7 years after anterior cruciate ligament reconstruction surgery. Am J Sports Med. 2012;40(1):41-8. http://dx.doi.org/10.1177/0363546511422999. PMid:21946441.

52. Gobbi A, Francisco R. Factors affecting return to sports after anterior cruciate ligament reconstruction with patellar tendon and hamstring graft: a prospective clinical investigation. Knee Surg Sports Traumatol Arthrosc. 2006;14(10):1021-8. http://dx.doi.org/10.1007/s00167-006-0050-9. PMid:16496124. 
53. Lee DY, Karim SA, Chang HC. Return to sports after anterior cruciate ligament reconstruction - a review of patients with minimum 5-year follow-up. Ann Acad Med Singapore. 2008;37(4):273-8. PMid:18461210.

54. Osti L, Liu SH, Raskin A, Merlo F, Bocchi L. Partial lateral meniscectomy in athletes. Arthroscopy. 1994;10(4):42430. http://dx.doi.org/10.1016/S0749-8063(05)80194-X. PMid:7945639.

55. Rangger C, Kathrein A, Klestil T, Glötzer W. Partial meniscectomy and osteoarthritis. Implications for treatment of athletes. Sports Med. 1997;23(1):61-8. http://dx.doi. org/10.2165/00007256-199723010-00006. PMid:9017860.

56. Jørgensen U, Sonne-Holm S, Lauridsen F, Rosenklint A. Long-term follow-up of meniscectomy in athletes. A prospective longitudinal study. J Bone Joint Surg Br. 1987;69(1):80-3. PMid:3818740.

57. Neyret P, Donell ST, DeJour D, DeJour H. Partial meniscectomy and anterior cruciate ligament rupture in soccer players. A study with a minimum 20-year followup. Am J Sports Med. 1993;21(3):455-60. http:// dx.doi.org/10.1177/036354659302100322. PMid:8346763.

58. Mithoefer K, Gill TJ, Cole BJ, Williams RJ, Mandelbaum BR. Clinical Outcome and Return to Competition after Microfracture in the Athlete's Knee: An Evidence-Based Systematic Review. Cartilage. 2010;1(2):113-20. http:// dx.doi.org/10.1177/1947603510366576. PMid:26069542.

59. Steadman JR, Miller BS, Karas SG, Schlegel TF, Briggs KK, Hawkins RJ. The microfracture technique in the treatment of full-thickness chondral lesions of the knee in National Football League players. J Knee Surg. 2003;16(2):83-6. PMid:12741420.

60. Namdari S, Baldwin K, Anakwenze O, Park M-J, Huffman GR, Sennett BJ. Results and performance after microfracture in National Basketball Association athletes. Am J Sports Med. 2009;37(5):943-8. http://dx.doi.org/10.1177/0363546508330150. PMid:19251677.

61. Harris JD, Walton DM, Erickson BJ, Verma NN, Abrams GD, Bush-Joseph CA, et al. Return to Sport and Performance After Microfracture in the Knees of National Basketball Association Players. Orthop J Sports Med. 2013;1(6). http:// dx.doi.org/10.1177/2325967113512759.

62. Mithoefer K, Peterson L, Saris DBF, Mandelbaum BR. Evolution and current role of autologous chondrocyte implantation for treatment of articular cartilage defects in the football (Soccer) player. Cartilage. 2012;3(1 Suppl):31S-6S. http:// dx.doi.org/10.1177/1947603511406532. PMid:26069604.

63. Van Assche D. Return to sport after cartilage repair: opportunities and pitfalls for rehabilitation. Proceedings of the International Cartilage Research Society, 2013 Sept 15-18; Ismir, Turkey. Los Angeles: Sage Publications; 2013. p. 1-3.

64. Rugg CM, Wang D, Sulzicki P, Hame SL. Effects of prior knee surgery on subsequent injury, imaging, and surgery in NCAA collegiate athletes. Am J Sports Med. 2014;42(4):959-64. http://dx.doi.org/10.1177/0363546513519951. PMid:24519183.

65. Kujala UM, Kettunen J, Paananen H, Aalto T, Battié MC, Impivaara $\mathrm{O}$, et al. Knee osteoarthritis in former runners, soccer players, weight lifters, and shooters. Arthritis
Rheum. 1995;38(4):539-46. http://dx.doi.org/10.1002/ art.1780380413. PMid:7718008.

66. Takeda H, Nakagawa T, Nakamura K, Engebretsen L. Prevention and management of knee osteoarthritis and knee cartilage injury in sports. Br J Sports Med. 2011;45(4):304-9. http:// dx.doi.org/10.1136/bjsm.2010.082321. PMid:21357577.

67. Øiestad BE, Engebretsen L, Storheim K, Risberg MA. Knee osteoarthritis after anterior cruciate ligament injury: a systematic review. Am J Sports Med. 2009;37(7):1434-43. http://dx.doi.org/10.1177/0363546509338827. PMid:19567666.

68. Kurtz S, Ong K, Lau E, Mowat F, Halpern M. Projections of primary and revision hip and knee arthroplasty in the United States from 2005 to 2030. J Bone Joint Surg Am. 2007;89(4):780-5. http://dx.doi.org/10.2106/JBJS.F.00222. PMid: 17403800 .

69. Flanigan DC, Everhart JS, Pedroza A, Smith T, Kaeding CC. Fear of reinjury (kinesiophobia) and persistent knee symptoms are common factors for lack of return to sport after anterior cruciate ligament reconstruction. Arthroscopy. 2013;29(8):1322-9. http://dx.doi.org/10.1016/j. arthro.2013.05.015. PMid:23906272.

70. Kim SG, Nagao M, Kamata K, Maeda K, Nozawa M. Return to sport after arthroscopic meniscectomy on stable knees. BMC Sports Sci Med Rehabil. 2013;5(1):23. http://dx.doi. org/10.1186/2052-1847-5-23. PMid:24257295.

71. Paterno MV, Rauh MJ, Schmitt LC, Ford KR, Hewett TE. Incidence of contralateral and ipsilateral anterior cruciate ligament (ACL) injury after primary ACL reconstruction and return to sport. Clin J Sport Med. 2012;22(2):11621. http://dx.doi.org/10.1097/JSM.0b013e318246ef9e. PMid:22343967.

72. Shelbourne KD, Gray T, Haro M. Incidence of subsequent injury to either knee within 5 years after anterior cruciate ligament reconstruction with patellar tendon autograft. Am J Sports Med. 2009;37(2):246-51. http://dx.doi. org/10.1177/0363546508325665. PMid:19109531.

73. van Eck CF, Schkrohowsky JG, Working ZM, Irrgang JJ, Fu FH. Prospective analysis of failure rate and predictors of failure after anatomic anterior cruciate ligament reconstruction with allograft. Am J Sports Med. 2012;40(4):800-7. http:// dx.doi.org/10.1177/0363546511432545. PMid:22238055.

74. Arendt E, Dick R. Knee injury patterns among men and women in collegiate basketball and soccer. NCAA data and review of literature. Am J Sports Med. 1995;23(6):694701. http://dx.doi.org/10.1177/036354659502300611. PMid:8600737.

75. Myklebust G, Engebretsen L, Braekken IH, Skjølberg A, Olsen OE, Bahr R. Prevention of anterior cruciate ligament injuries in female team handball players: a prospective intervention study over three seasons. Clin J Sport Med. 2003;13(2):71-8. http://dx.doi.org/10.1097/00042752200303000-00002. PMid:12629423.

76. Ryan J, Magnussen RA, Cox CL, Hurbanek JG, Flanigan DC, Kaeding CC. ACL reconstruction: do outcomes differ by sex? A systematic review. J Bone Joint Surg Am. 2014;96(6):507-12. http://dx.doi.org/10.2106/JBJS.M.00299. PMid:24647508.

77. Dunn WR, Spindler KP, Amendola A, Andrish JT, Bergfeld JA, Flanigan DC, et al. Predictors of activity level 2 years after anterior cruciate ligament reconstruction (ACLR): 
a Multicenter Orthopaedic Outcomes Network (MOON) ACLR cohort study. Am J Sports Med. 2010;38(10):2040-50. http://dx.doi.org/10.1177/0363546510370280. PMid:20709944.

78. Spindler KP, Huston LJ, Wright RW, Kaeding CC, Marx $\mathrm{RG}$, Amendola A, et al. The prognosis and predictors of sports function and activity at minimum 6 years after anterior cruciate ligament reconstruction: a population cohort study. Am J Sports Med. 2011;39(2):348-59. http:// dx.doi.org/10.1177/0363546510383481. PMid:21084660.

79. Mayr HO, Weig TG, Plitz W. Arthrofibrosis following ACL reconstruction--reasons and outcome. Arch Orthop Trauma Surg. 2004;124(8):518-22. http://dx.doi.org/10.1007/ s00402-004-0718-x. PMid:15480713.

80. Paulos LE, Rosenberg TD, Drawbert J, Manning J, Abbott P. Infrapatellar contracture syndrome. An unrecognized cause of knee stiffness with patella entrapment and patella infera. Am J Sports Med. 1987;15(4):331-41. http://dx.doi. org/10.1177/036354658701500407. PMid:3661814.

81. Shelbourne KD, Patel DV, Martini DJ. Classification and management of arthrofibrosis of the knee after anterior cruciate ligament reconstruction. Am J Sports Med. 1996;24(6):85762. http://dx.doi.org/10.1177/036354659602400625. PMid:8947412.

82. Ericsson YB, Roos EM, Dahlberg L. Muscle strength, functional performance, and self-reported outcomes four years after arthroscopic partial meniscectomy in middleaged patients. Arthritis Rheum. 2006;55(6):946-52. http:// dx.doi.org/10.1002/art.22346. PMid:17139641.

83. Logerstedt D, Lynch A, Axe MJ, Snyder-Mackler L. Symmetry restoration and functional recovery before and after anterior cruciate ligament reconstruction. Knee Surg Sports Traumatol Arthrosc. 2013;21(4):859-68. http:// dx.doi.org/10.1007/s00167-012-1929-2. PMid:22349604.

84. Palmieri-Smith RM, Thomas AC, Wojtys EM. Maximizing quadriceps strength after ACL reconstruction. Clin Sports Med. 2008;27(3):405-24, vii-ix. http://dx.doi.org/10.1016/j. csm.2008.02.001. PMid:18503875.

85. Van Assche D, Staes F, Van Caspel D, Vanlauwe J, Bellemans J, Saris DB, et al. Autologous chondrocyte implantation versus microfracture for knee cartilage injury: a prospective randomized trial, with 2-year follow-up. Knee Surg Sports Traumatol Arthrosc. 2010;18(4):486-95. http://dx.doi. org/10.1007/s00167-009-0955-1. PMid:19820916.

86. Hartigan EH, Axe MJ, Snyder-Mackler L. Time line for noncopers to pass return-to-sports criteria after anterior cruciate ligament reconstruction. J Orthop Sports Phys Ther. 2010;40(3):141-54. http://dx.doi.org/10.2519/jospt.2010.3168. PMid:20195019.

87. Mithoefer K, Hambly K, Logerstedt D, Ricci M, Silvers H, Della Villa S. Current concepts for rehabilitation and return to sport after knee articular cartilage repair in the athlete. J Orthop Sports Phys Ther. 2012;42(3):254-73. http://dx.doi.org/10.2519/jospt.2012.3665. PMid:22383103.

88. Myer GD, Paterno MV, Ford KR, Quatman CE, Hewett TE. Rehabilitation after anterior cruciate ligament reconstruction: criteria-based progression through the return-to-sport phase. J Orthop Sports Phys Ther. 2006;36(6):385-402. http://dx.doi.org/10.2519/jospt.2006.2222. PMid:16776488.

89. Thomeé R, Kaplan Y, Kvist J, Myklebust G, Risberg MA, Theisen D, et al. Muscle strength and hop performance criteria prior to return to sports after ACL reconstruction. Knee Surg Sports Traumatol Arthrosc. 2011;19(11):1798-805. http://dx.doi.org/10.1007/s00167-011-1669-8. PMid:21932078.

90. Chmielewski TL, Stackhouse S, Axe MJ, Snyder-Mackler L. A prospective analysis of incidence and severity of quadriceps inhibition in a consecutive sample of 100 patients with complete acute anterior cruciate ligament rupture. J Orthop Res. 2004;22(5):925-30. http://dx.doi. org/10.1016/j.orthres.2004.01.007. PMid:15304261.

91. Hurd WJ, Axe MJ, Snyder-Mackler L. A 10-year prospective trial of a patient management algorithm and screening examination for highly active individuals with anterior cruciate ligament injury: Part 1, outcomes. Am J Sports Med. 2008;36(1):40-7. http://dx.doi.org/10.1177/0363546507308190. PMid:17940141.

92. Jong SN, van Caspel DR, van Haeff MJ, Saris DB. Functional assessment and muscle strength before and after reconstruction of chronic anterior cruciate ligament lesions. Arthroscopy. 2007;23(1):21-8. http://dx.doi.org/10.1016/j. arthro.2006.08.024. PMid:17210423.

93. Eitzen I, Holm I, Risberg MA. Preoperative quadriceps strength is a significant predictor of knee function two years after anterior cruciate ligament reconstruction. $\mathrm{Br}$ J Sports Med. 2009;43(5):371-6. http://dx.doi.org/10.1136/ bjsm.2008.057059. PMid:19224907.

94. Logerstedt D, Lynch A, Axe MJ, Snyder-Mackler L. Preoperative quadriceps strength predicts IKDC2000 scores 6 months after anterior cruciate ligament reconstruction. Knee. 2013;20(3):208-12. http://dx.doi.org/10.1016/j knee.2012.07.011. PMid:23022031.

95. Ingersoll CD, Grindstaff TL, Pietrosimone BG, Hart JM. Neuromuscular consequences of anterior cruciate ligament injury. Clin Sports Med. 2008;27(3):383-404, vii. http:// dx.doi.org/10.1016/j.csm.2008.03.004. PMid:18503874.

96. Keays SL, Bullock-Saxton JE, Keays AC, Newcombe PA, Bullock MI. A 6-year follow-up of the effect of graft site on strength, stability, range of motion, function, and joint degeneration after anterior cruciate ligament reconstruction: patellar tendon versus semitendinosus and Gracilis tendon graft. Am J Sports Med. 2007;35(5):729-39. http://dx.doi. org/10.1177/0363546506298277. PMid:17322130.

97. Anderson AF, Dome DC, Gautam S, Awh MH, Rennirt GW Correlation of anthropometric measurements, strength, anterior cruciate ligament size, and intercondylar notch characteristics to sex differences in anterior cruciate ligament tear rates. Am J Sports Med. 2001;29(1):58-66. PMid:11206258.

98. Aune AK, Holm I, Risberg MA, Jensen HK, Steen H. Fourstrand hamstring tendon autograft compared with patellar tendon-bone autograft for anterior cruciate ligament reconstruction. A randomized study with two-year followup. Am J Sports Med. 2001;29(6):722-8. PMid:11734484.

99. Feller JA, Webster KE. A randomized comparison of patellar tendon and hamstring tendon anterior cruciate ligament reconstruction. Am J Sports Med. 2003;31(4):564-73. PMid:12860546.

100. Gobbi A, Mahajan S, Zanazzo M, Tuy B. Patellar tendon versus quadrupled bone-semitendinosus anterior cruciate ligament reconstruction: a prospective clinical investigation 
in athletes. Arthroscopy. 2003;19(6):592-601. http://dx.doi. org/10.1016/S0749-8063(03)00393-1. PMid:12861197.

101. McLeod MM, Gribble P, Pfile KR, Pietrosimone BG. Effects of arthroscopic partial meniscectomy on quadriceps strength: a systematic review. J Sport Rehabil. 2012;21(3):285-95. PMid:22234935.

102. Witvrouw E, Bellemans J, Verdonk R, Cambier D, Coorevits P, Almqvist F. Patellar tendon vs. doubled semitendinosus and gracilis tendon for anterior cruciate ligament reconstruction. Int Orthop. 2001;25(5):308-11. http://dx.doi.org/10.1007/ s002640100268. PMid:11794266.

103. Ardern CL, Webster KE, Taylor NF, Feller JA. Hamstring strength recovery after hamstring tendon harvest for anterior cruciate ligament reconstruction: a comparison between graft types. Arthroscopy. 2010;26(4):462-9. http:// dx.doi.org/10.1016/j.arthro.2009.08.018. PMid:20362824.

104. Keays SL, Bullock-Saxton JE, Newcombe P, Keays AC. The relationship between knee strength and functional stability before and after anterior cruciate ligament reconstruction. J Orthop Res. 2003;21(2):231-7. http://dx.doi.org/10.1016/ S0736-0266(02)00160-2. PMid:12568953.

105. Samuelsson K, Andersson D, Karlsson J. Treatment of anterior cruciate ligament injuries with special reference to graft type and surgical technique: an assessment of randomized controlled trials. Arthroscopy. 2009;25(10):1139-74. http:// dx.doi.org/10.1016/j.arthro.2009.07.021. PMid:19801293.

106. Myer GD, Ford KR, Barber Foss KD, Liu C, Nick TG, Hewett TE. The relationship of hamstrings and quadriceps strength to anterior cruciate ligament injury in female athletes. Clin J Sport Med. 2009;19(1):3-8. http://dx.doi. org/10.1097/JSM.0b013e318190bddb. PMid:19124976.

107. Myer GD, Ford KR, Khoury J, Succop P, Hewett TE. Biomechanics laboratory-based prediction algorithm to identify female athletes with high knee loads that increase risk of ACL injury. Br J Sports Med. 2011;45(4):245-52. http://dx.doi.org/10.1136/bjsm.2009.069351. PMid:20558526.

108. Roewer BD, Di Stasi SL, Snyder-Mackler L. Quadriceps strength and weight acceptance strategies continue to improve two years after anterior cruciate ligament reconstruction. J Biomech. 2011;44(10):1948-53. http:// dx.doi.org/10.1016/j.jbiomech.2011.04.037. PMid:21592482.

109. Otzel DM, Chow JW, Tillman MD. Long-term deficits in quadriceps strength and activation following anterior cruciate ligament reconstruction. Phys Ther Sport. 2015;16(1):22-8. http://dx.doi.org/10.1016/j.ptsp.2014.02.003. PMid:24933688.

110. Schmitt LC, Quatman CE, Paterno MV, Best TM, Flanigan DC. Functional outcomes after surgical management of articular cartilage lesions in the knee: a systematic literature review to guide postoperative rehabilitation. J Orthop Sports Phys Ther. 2014;44(8):565-A10. http:// dx.doi.org/10.2519/jospt.2014.4844. PMid:24955815.

111. Van Assche D, Staes F, Van Caspel D, Vanlauwe J, Bellemans J, Saris DB, et al. Autologous chondrocyte implantation versus microfracture for knee cartilage injury: a prospective randomized trial, with 2-year follow-up. Knee Surg Sports Traumatol Arthrosc. 2010;18(4):486-95. http://dx.doi. org/10.1007/s00167-009-0955-1. PMid:19820916.

112. Kreuz PC, Müller S, Freymann U, Erggelet C, Niemeyer $\mathrm{P}$, Kaps C, et al. Repair of focal cartilage defects with scaffold-assisted autologous chondrocyte grafts: clinical and biomechanical results 48 months after transplantation. Am J Sports Med. 2011;39(8):1697-705. http://dx.doi. org/10.1177/0363546511403279. PMid:21540360.

113. Ebert JR, Lloyd DG, Wood DJ, Ackland TR. Isokinetic knee extensor strength deficit following matrix-induced autologous chondrocyte implantation. Clin Biomech (Bristol, Avon). 2012;27(6):588-94. http://dx.doi.org/10.1016/j. clinbiomech.2012.01.006. PMid:22341772.

114. Løken S, Ludvigsen TC, Høysveen T, Holm I, Engebretsen L, Reinholt FP. Autologous chondrocyte implantation to repair knee cartilage injury: ultrastructural evaluation at 2 years and long-term follow-up including muscle strength measurements. Knee Surg Sports Traumatol Arthrosc. 2009;17(11):1278-88. http://dx.doi.org/10.1007/s00167009-0854-5. PMid:19572120.

115. Schmitt LC, Paterno MV, Hewett TE. The impact of quadriceps femoris strength asymmetry on functional performance at return to sport following anterior cruciate ligament reconstruction. J Orthop Sports Phys Ther. 2012;42(9):750-9. http://dx.doi.org/10.2519/jospt.2012.4194. PMid:22813542.

116. Ericsson YB, Roos EM, Dahlberg L. Muscle strength, functional performance, and self-reported outcomes four years after arthroscopic partial meniscectomy in middleaged patients. Arthritis Rheum. 2006;55(6):946-52. http:// dx.doi.org/10.1002/art.22346. PMid:17139641.

117. Roos EM, Roos HP, Lohmander LS, Ekdahl C, Beynnon BD. Knee Injury and Osteoarthritis Outcome Score (KOOS)-development of a self-administered outcome measure. J Orthop Sports Phys Ther. 1998;28(2):88-96. http://dx.doi. org/10.2519/jospt.1998.28.2.88. PMid:9699158.

118. Thorlund JB, Aagaard P, Roos EM. Muscle strength and functional performance in patients at high risk of knee osteoarthritis: a follow-up study. Knee Surg Sports Traumatol Arthrosc. 2012;20(6):1110-7. http://dx.doi.org/10.1007/ s00167-011-1719-2. PMid:22037811.

119. Gribble PA, Hertel J, Plisky P. Using the Star Excursion Balance Test to assess dynamic postural-control deficits and outcomes in lower extremity injury: a literature and systematic review. J Athl Train. 2012;47(3):339-57. PMid:22892416.

120. Hewett TE, Paterno MV, Myer GD. Strategies for enhancing proprioception and neuromuscular control of the knee. Clin Orthop Relat Res. 2002;402:76-94. http://dx.doi. org/10.1097/00003086-200209000-00008. PMid:12218474.

121. Paterno MV, Schmitt LC, Ford KR, Rauh MJ, Hewett TE. Altered postural sway persists after anterior cruciate ligament reconstruction and return to sport. Gait Posture. 2013;38(1):136-40. http://dx.doi.org/10.1016/j. gaitpost.2012.11.001. PMid:23219783.

122. Plisky PJ, Rauh MJ, Kaminski TW, Underwood FB. Star Excursion Balance Test as a predictor of lower extremity injury in high school basketball players. J Orthop Sports Phys Ther. 2006;36(12):911-9. http://dx.doi.org/10.2519/ jospt.2006.2244. PMid:17193868.

123. Reid A, Birmingham TB, Stratford PW, Alcock GK, Giffin JR. Hop testing provides a reliable and valid outcome measure during rehabilitation after anterior cruciate ligament reconstruction. Phys Ther. 2007;87(3):337-49. http://dx.doi.org/10.2522/ptj.20060143. PMid:17311886. 
124. Myer GD, Schmitt LC, Brent JL, Ford KR, Barber Foss $\mathrm{KD}$, Scherer BJ, et al. Utilization of modified NFL combine testing to identify functional deficits in athletes following ACL reconstruction. J Orthop Sports Phys Ther. 2011;41(6):377-87. http://dx.doi.org/10.2519/jospt.2011.3547. PMid:21289456.

125. Fitzgerald GK, Lephart SM, Hwang JH, Wainner RS. Hop tests as predictors of dynamic knee stability. J Orthop Sports Phys Ther. 2001;31(10):588-97. http://dx.doi.org/10.2519/ jospt.2001.31.10.588. PMid:11665746.

126. Juris PM, Phillips EM, Dalpe C, Edwards C, Gotlin RS, Kane DJ.A dynamic test of lower extremity function following anterior cruciate ligament reconstruction and rehabilitation. J Orthop Sports Phys Ther. 1997;26(4):184-91. http://dx.doi. org/10.2519/jospt.1997.26.4.184. PMid:9310909.

127. Ross MD, Langford B, Whelan PJ. Test-retest reliability of 4 single-leg horizontal hop tests. J Strength Cond Res. 2002;16(4):617-22. PMid:12423195.

128. Wilk KE, Romaniello WT, Soscia SM, Arrigo CA, Andrews JR. The relationship between subjective knee scores, isokinetic testing, and functional testing in the ACL-reconstructed knee. J Orthop Sports Phys Ther. 1994;20(2):60-73. http:// dx.doi.org/10.2519/jospt.1994.20.2.60. PMid:7920603.

129. Hopper DM, Strauss GR, Boyle JJ, Bell J. Functional recovery after anterior cruciate ligament reconstruction: a longitudinal perspective. Arch Phys Med Rehabil. 2008;89(8):1535-41. http://dx.doi.org/10.1016/j.apmr.2007.11.057. PMid:18586220.

130. Lephart SM, Perrin DH, Fu FH, Gieck JH, McCue FC 3rd, Irrgang JJ. Relationship between Selected Physical Characteristics and Functional Capacity in the Anterior Cruciate Ligament-Insufficient Athlete. J Orthop Sports Phys Ther. 1992;16(4):174-81. http://dx.doi.org/10.2519/ jospt.1992.16.4.174. PMid:18796757.

131. Logerstedt DS, Snyder-Mackler L, Ritter RC, Axe MJ, Godges JJ, Orthopaedic Section of the American Physical Therapist Association. Knee stability and movement coordination impairments: knee ligament sprain. J Orthop Sports Phys Ther. 2010;40(4):A1-37. http://dx.doi.org/10.2519/ jospt.2010.0303. PMid:20357420.

132. Noyes FR, Barber SD, Mangine RE. Abnormal lower limb symmetry determined by function hop tests after anterior cruciate ligament rupture. Am J Sports Med. 1991;19(5):513-8. http://dx.doi.org/10.1177/036354659101900518. PMid:1962720.

133. Daniel DM, Malcom LL, Losse G, Stone ML, Sachs R, Burks R. Instrumented measurement of anterior laxity of the knee. J Bone Joint Surg Am. 1985;67(5):720-6. PMid:3997924.

134. O’Donnell S, Thomas SG, Marks P. Improving the sensitivity of the hop index in patients with an ACL deficient knee by transforming the hop distance scores. BMC Musculoskelet Disord. 2006;7(1):9. http://dx.doi.org/10.1186/1471-24747-9. PMid:16448576.

135. Xergia SA, Pappas E, Zampeli F, Georgiou S, Georgoulis AD. Asymmetries in functional hop tests, lower extremity kinematics, and isokinetic strength persist 6 to 9 months following anterior cruciate ligament reconstruction. J Orthop Sports Phys Ther. 2013;43(3):154-62. http://dx.doi. org/10.2519/jospt.2013.3967. PMid:23322072.

136. Thorlund JB, Aagaard P, Roos EM. Muscle strength and functional performance in patients at high risk of knee osteoarthritis: a follow-up study. Knee Surg Sports Traumatol Arthrosc. 2012;20(6):1110-7. http://dx.doi.org/10.1007/ s00167-011-1719-2. PMid:22037811.

137. Grindem H, Logerstedt D, Eitzen I, Moksnes H, Axe MJ, Snyder-Mackler L, et al. Single-legged hop tests as predictors of self-reported knee function in nonoperatively treated individuals with anterior cruciate ligament injury. Am J Sports Med. 2011;39(11):2347-54. http://dx.doi. org/10.1177/0363546511417085. PMid:21828364.

138. Logerstedt D, Grindem H, Lynch A, Eitzen I, Engebretsen L, Risberg MA, et al. Single-legged hop tests as predictors of self-reported knee function after anterior cruciate ligament reconstruction: the Delaware-Oslo ACL cohort study. Am J Sports Med. 2012;40(10):2348-56. http://dx.doi. org/10.1177/0363546512457551. PMid:22926749.

139. Holsgaard-Larsen A, Jensen C, Mortensen NHM, Aagaard P. Concurrent assessments of lower limb loading patterns, mechanical muscle strength and functional performance in ACL-patients--a cross-sectional study. Knee. 2014;21(1):66-73. http://dx.doi.org/10.1016/j.knee.2013.06.002. PMid:23835518

140. Cascio BM, Culp L, Cosgarea AJ. Return to play after anterior cruciate ligament reconstruction. Clin Sports Med. 2004;23(3):395-408, ix. http://dx.doi.org/10.1016/j. csm.2004.03.004. PMid:15262378.

141. Marx RG, Jones EC, Angel M, Wickiewicz TL, Warren RF. Beliefs and attitudes of members of the American Academy of Orthopaedic Surgeons regarding the treatment of anterior cruciate ligament injury. Arthroscopy. 2003;19(7):76270. http://dx.doi.org/10.1016/S0749-8063(03)00398-0. PMid:12966385.

142. Barber SD, Noyes FR, Mangine RE, McCloskey JW, Hartman W. Quantitative assessment of functional limitations in normal and anterior cruciate ligament-deficient knees. Clin Orthop Relat Res. 1990;(255):204-14. PMid:2347154.

143. Shelbourne KD, Klotz C. What I have learned about the ACL: utilizing a progressive rehabilitation scheme to achieve total knee symmetry after anterior cruciate ligament reconstruction. J Orthop Sci. 2006;11(3):318-25. http:// dx.doi.org/10.1007/s00776-006-1007-z. PMid:16721538.

144. Creighton DW, Shrier I, Shultz R, Meeuwisse WH, Matheson GO. Return-to-play in sport: a decision-based model. Clin J Sport Med. 2010;20(5):379-85. http://dx.doi.org/10.1097/ JSM.0b013e3181f3c0fe. PMid:20818198.

145. Lentz TA, Zeppieri G Jr, Tillman SM, Indelicato PA, Moser MW, George SZ, et al. Return to preinjury sports participation following anterior cruciate ligament reconstruction: contributions of demographic, knee impairment, and self-report measures. J Orthop Sports Phys Ther. 2012;42(11):893-901. http://dx.doi.org/10.2519/ jospt.2012.4077. PMid:22951437.

146. Silbernagel KG, Thomeé R, Eriksson BI, Karlsson J. Continued sports activity, using a pain-monitoring model, during rehabilitation in patients with Achilles tendinopathy: a randomized controlled study. Am J Sports Med. 2007;35(6):897906. http://dx.doi.org/10.1177/0363546506298279. PMid: 17307888.

147. Adams D, Logerstedt DS, Hunter-Giordano A, Axe MJ, Snyder-Mackler L. Current concepts for anterior cruciate ligament reconstruction: a criterion-based rehabilitation 
progression. J Orthop Sports Phys Ther. 2012;42(7):601-14. http://dx.doi.org/10.2519/jospt.2012.3871. PMid:22402434

148. Sturgill LP, Snyder-Mackler L, Manal TJ, Axe MJ. Interrater reliability of a clinical scale to assess knee joint effusion. J Orthop Sports Phys Ther. 2009;39(12):845-9. http://dx.doi. org/10.2519/jospt.2009.3143. PMid:20032559.

149. Lynch AD, Logerstedt DS, Axe MJ, Snyder-Mackler L. Quadriceps activation failure after anterior cruciate ligament rupture is not mediated by knee joint effusion. $\mathrm{J}$ Orthop Sports Phys Ther. 2012;42(6):502-10. http://dx.doi. org/10.2519/jospt.2012.3793. PMid:22523081

150. Palmieri-Smith RM, Kreinbrink J, Ashton-Miller JA, Wojtys EM. Quadriceps inhibition induced by an experimental knee joint effusion affects knee joint mechanics during a singlelegged drop landing. Am J Sports Med. 2007;35(8):1269-75. http://dx.doi.org/10.1177/0363546506296417. PMid:17244901.

151. Eastlack ME, Axe MJ, Snyder-Mackler L. Laxity, instability, and functional outcome after ACL injury: copers versus noncopers. Med Sci Sports Exerc. 1999;31(2):210-5. http://dx.doi.org/10.1097/00005768-199902000-00002. PMid:10063808.

152. Engström B, Gornitzka J, Johansson C, Wredmark T. Knee function after anterior cruciate ligament ruptures treated conservatively. Int Orthop. 1993;17(4):208-13. http://dx.doi. org/10.1007/BF00194180. PMid:8407034.

153. Snyder-Mackler L, Fitzgerald GK, Bartolozzi AR 3rd, Ciccotti MG. The relationship between passive joint laxity and functional outcome after anterior cruciate ligament injury. Am J Sports Med. 1997;25(2):191-5. http://dx.doi. org/10.1177/036354659702500209. PMid:9079172.

154. Hewett TE, Di Stasi SL, Myer GD. Current concepts for injury prevention in athletes after anterior cruciate ligament reconstruction. Am J Sports Med. 2013;41(1):216-24. http:// dx.doi.org/10.1177/0363546512459638. PMid:23041233.

155. Chmielewski TL, Hurd WJ, Rudolph KS, Axe MJ, SnyderMackler L. Perturbation training improves knee kinematics and reduces muscle co-contraction after complete unilateral anterior cruciate ligament rupture. Phys Ther. 2005;85(8):740-9, discussion 750-4. PMid:16048422.

156. Di Stasi SL, Logerstedt D, Gardinier ES, Snyder-Mackler L. Gait patterns differ between ACL-reconstructed athletes who pass return-to-sport criteria and those who fail. Am J Sports Med. 2013;41(6):1310-8. http://dx.doi. org/10.1177/0363546513482718. PMid:23562809.

157. Ebert JR, Lloyd DG, Ackland T, Wood DJ. Knee biomechanics during walking gait following matrix-induced autologous chondrocyte implantation. Clin Biomech (Bristol, Avon). 2010;25(10):1011-7. http://dx.doi.org/10.1016/j. clinbiomech.2010.07.004. PMid:20692745.

158. Paterno MV, Schmitt LC, Ford KR, Rauh MJ, Myer GD, Huang B, et al. Biomechanical measures during landing and postural stability predict second anterior cruciate ligament injury after anterior cruciate ligament reconstruction and return to sport. Am J Sports Med. 2010;38(10):1968-78. http:// dx.doi.org/10.1177/0363546510376053. PMid:20702858.

159. Lewek M, Rudolph K, Axe M, Snyder-Mackler L. The effect of insufficient quadriceps strength on gait after anterior cruciate ligament reconstruction. Clin Biomech (Bristol, Avon). 2002;17(1):56-63. http://dx.doi.org/10.1016/ S0268-0033(01)00097-3. PMid:11779647.
160. Di Stasi SL, Logerstedt D, Gardinier ES, Snyder-Mackler L. Gait patterns differ between ACL-reconstructed athletes who pass return-to-sport criteria and those who fail. Am J Sports Med. 2013;41(6):1310-8. http://dx.doi. org/10.1177/0363546513482718. PMid:23562809.

161. Paterno MV, Ford KR, Myer GD, Heyl R, Hewett TE. Limb asymmetries in landing and jumping 2 years following anterior cruciate ligament reconstruction. Clin J Sport Med. 2007;17(4):258-62. http://dx.doi.org/10.1097/ JSM.0b013e31804c77ea. PMid:17620778.

162. Ernst GP, Saliba E, Diduch DR, Hurwitz SR, Ball DW. Lower extremity compensations following anterior cruciate ligament reconstruction. Phys Ther. 2000;80(3):251-60. PMid:10696152.

163. Sturnieks DL, Besier TF, Mills PM, Ackland TR, Maguire $\mathrm{KF}$, Stachowiak GW, et al. Knee joint biomechanics following arthroscopic partial meniscectomy. J Orthop Res. 2008;26(8):1075-80. http://dx.doi.org/10.1002/jor.20610. PMid:18327795.

164. Sturnieks DL, Besier TF, Hamer PW, Ackland TR, Mills PM, Stachowiak GW, et al. Knee strength and knee adduction moments following arthroscopic partial meniscectomy. Med Sci Sports Exerc. 2008;40(6):991-7. http://dx.doi. org/10.1249/MSS.0b013e318167812a. PMid:18461009.

165. Bulgheroni P, Bulgheroni MV, Ronga M, Manelli A. Gait analysis of pre- and post-meniscectomy knee: a prospective study. Knee. 2007;14(6):472-7. http://dx.doi.org/10.1016/j. knee.2007.08.003. PMid:17942312.

166. Ebert JR, Robertson WB, Lloyd DG, Zheng MH, Wood DJ, Ackland T. Traditional vs accelerated approaches to post-operative rehabilitation following matrix-induced autologous chondrocyte implantation (MACI): comparison of clinical, biomechanical and radiographic outcomes. Osteoarthritis Cartilage. 2008;16(10):1131-40. http://dx.doi. org/10.1016/j.joca.2008.03.010. PMid:18434214.

167. Andriacchi TP, Mündermann A, Smith RL, Alexander EJ, Dyrby $\mathrm{CO}, \mathrm{Koo} \mathrm{S}$. A framework for the in vivo pathomechanics of osteoarthritis at the knee. Ann Biomed Eng. 2004;32(3):44757. http://dx.doi.org/10.1023/B:ABME.0000017541.82498.37. PMid:15095819.

168. Defrate LE, Papannagari R, Gill TJ, Moses JM, Pathare NP, Li G. The 6 degrees of freedom kinematics of the knee after anterior cruciate ligament deficiency: an in vivo imaging analysis. Am J Sports Med. 2006;34(8):1240-6. http://dx.doi. org/10.1177/0363546506287299. PMid:16636348.

169. Gardinier ES, Manal K, Buchanan TS, Snyder-Mackler L. Gait and neuromuscular asymmetries after acute anterior cruciate ligament rupture. Med Sci Sports Exerc. 2012;44(8):14906. http://dx.doi.org/10.1249/MSS.0b013e31824d2783. PMid:22330021.

170. Baliunas AJ, Hurwitz DE, Ryals AB, Karrar A, Case JP, Block $\mathrm{JA}$, et al. Increased knee joint loads during walking are present in subjects with knee osteoarthritis. Osteoarthritis Cartilage. 2002;10(7):573-9. http://dx.doi.org/10.1053/ joca.2002.0797. PMid:12127838.

171. Childs JD, Sparto PJ, Fitzgerald GK, Bizzini M, Irrgang JJ. Alterations in lower extremity movement and muscle activation patterns in individuals with knee osteoarthritis. Clin Biomech (Bristol, Avon). 2004;19(1):44-9. http://dx.doi. org/10.1016/j.clinbiomech.2003.08.007. PMid:14659929. 
172. Griffin TM, Guilak F. The role of mechanical loading in the onset and progression of osteoarthritis. Exerc Sport Sci Rev. 2005;33(4):195-200. http://dx.doi.org/10.1097/00003677200510000-00008. PMid:16239837.

173. Irrgang JJ, Anderson AF, Boland AL, Harner CD, Kurosaka $\mathrm{M}$, Neyret P, et al. Development and validation of the international knee documentation committee subjective knee form. Am J Sports Med. 2001;29(5):600-13. PMid:11573919.

174. Pantano KJ, Irrgang JJ, Burdett R, Delitto A, Harner C, Fu FH. A pilot study on the relationship between physical impairment and activity restriction in persons with anterior cruciate ligament reconstruction at long-term follow-up. Knee Surg Sports Traumatol Arthrosc. 2001;9(6):369-78. http://dx.doi.org/10.1007/s001670100239. PMid:11734876.

175. Kocher MS, Steadman JR, Briggs K, Zurakowski D, Sterett WI, Hawkins RJ. Determinants of patient satisfaction with outcome after anterior cruciate ligament reconstruction. J Bone Joint Surg Am. 2002;84-A(9):1560-72. PMid:12208912.

176. Borsa PA, Lephart SM, Irrgang JJ. Comparison of performance-based and patient-reported measures of function in anterior-cruciate-ligament-deficient individuals. J Orthop Sports Phys Ther. 1998;28(6):392-9. http://dx.doi. org/10.2519/jospt.1998.28.6.392. PMid:9836170.

177. Marx RG, Jones EC, Allen AA, Altchek DW, O’Brien SJ, Rodeo SA, et al. Reliability, validity, and responsiveness of four knee outcome scales for athletic patients. J Bone Joint Surg Am. 2001;83-A(10):1459-69. PMid:11679594.

178. Eitzen I, Moksnes H, Snyder-Mackler L, Engebretsen L, Risberg MA. Functional tests should be accentuated more in the decision for ACL reconstruction. Knee Surg Sports Traumatol Arthrosc. 2010;18(11):1517-25. http://dx.doi. org/10.1007/s00167-010-1113-5. PMid:20411377.

179. Branch TP, Siebold R, Freedberg HI, Jacobs CA. Doublebundle ACL reconstruction demonstrated superior clinical stability to single-bundle ACL reconstruction: a matched-pairs analysis of instrumented tests of tibial anterior translation and internal rotation laxity. Knee Surg Sports Traumatol Arthrosc. 2011;19(3):432-40. http://dx.doi. org/10.1007/s00167-010-1247-5. PMid:20814662.

180. Hartigan EH, Axe MJ, Snyder-Mackler L. Time line for noncopers to pass return-to-sports criteria after anterior cruciate ligament reconstruction. J Orthop Sports Phys Ther. 2010;40(3):141-54. http://dx.doi.org/10.2519/jospt.2010.3168. PMid:20195019.

181. Murray JRD, Lindh AM, Hogan NA, Trezies AJ, Hutchinson JW, Parish E, et al. Does anterior cruciate ligament reconstruction lead to degenerative disease?: Thirteenyear results after bone-patellar tendon-bone autograft. Am J Sports Med. 2012;40(2):404-13. http://dx.doi. org/10.1177/0363546511428580. PMid:22116668.

182. Risberg MA, Holm I, Tjomsland O, Ljunggren E, Ekeland A. Prospective study of changes in impairments and disabilities after anterior cruciate ligament reconstruction. J Orthop Sports Phys Ther. 1999;29(7):400-12. http://dx.doi. org/10.2519/jospt.1999.29.7.400. PMid:10416180.

183. Mithoefer K, McAdams T, Williams RJ, Kreuz PC, Mandelbaum BR. Clinical efficacy of the microfracture technique for articular cartilage repair in the knee: an evidence-based systematic analysis. Am J Sports Med. 2009;37(10):2053-63. http://dx.doi.org/10.1177/0363546508328414. PMid:19251676.
184. Mithoefer K, Williams RJ 3rd, Warren RF, Wickiewicz TL, Marx RG. High-impact athletics after knee articular cartilage repair: a prospective evaluation of the microfracture technique. Am J Sports Med. 2006;34(9):1413-8. http:/ dx.doi.org/10.1177/0363546506288240. PMid:16735588.

185. Gobbi A, Karnatzikos G, Kumar A. Long-term results after microfracture treatment for full-thickness knee chondral lesions in athletes. Knee Surg Sports Traumatol Arthrosc. 2014;22(9):1986-96. PMid:24051505.

186. Krych AJ, Robertson CM, Williams RJ 3rd; Cartilage Study Group. Return to athletic activity after osteochondral allograft transplantation in the knee. Am J Sports Med. 2012;40(5):1053-9. http://dx.doi.org/10.1177/0363546511435780. PMid:22316548.

187. Kreuz PC, Steinwachs M, Erggelet C, Lahm A, Krause $\mathrm{S}$, Ossendorf C, et al. Importance of sports in cartilage regeneration after autologous chondrocyte implantation: a prospective study with a 3-year follow-up. Am J Sports Med. 2007;35(8):1261-8. http://dx.doi.org/10.1177/0363546507300693. PMid:17405884.

188. Ebert JR, Robertson WB, Woodhouse J, Fallon M, Zheng MH, Ackland T, et al. Clinical and magnetic resonance imagingbased outcomes to 5 years after matrix-induced autologous chondrocyte implantation to address articular cartilage defects in the knee. Am J Sports Med. 2011;39(4):753-63. http://dx.doi.org/10.1177/0363546510390476. PMid:21257846.

189. Marlovits S, Aldrian S, Wondrasch B, Zak L, Albrecht C, Welsch G, et al. Clinical and radiological outcomes 5 years after matrix-induced autologous chondrocyte implantation in patients with symptomatic, traumatic chondral defects. Am J Sports Med. 2012;40(10):2273-80. http://dx.doi. org/10.1177/0363546512457008. PMid:22922521.

190. Meeuwisse WH, Tyreman H, Hagel B, Emery C. Adynamic model of etiology in sport injury: the recursive nature of risk and causation. Clin J Sport Med. 2007;17(3):2159. http://dx.doi.org/10.1097/JSM.0b013e3180592a48. PMid:17513916.

191. Czuppon S, Racette BA, Klein SE, Harris-Hayes M. Variables associated with return to sport following anterior cruciate ligament reconstruction: a systematic review. $\mathrm{Br}$ J Sports Med. 2014;48(5):356-64. http://dx.doi.org/10.1136/ bjsports-2012-091786. PMid:24124040.

192. Schmitt LC, Paterno MV, Hewett TE. The impact of quadriceps femoris strength asymmetry on functional performance at return to sport following anterior cruciate ligament reconstruction. J Orthop Sports Phys Ther. 2012;42(9):750-9. http://dx.doi.org/10.2519/jospt.2012.4194. PMid:22813542.

193. Kiesel K, Plisky PJ, Voight ML. Can Serious Injury in Professional Football be Predicted by a Preseason Functional Movement Screen? N Am J Sports Phys Ther. 2007;2(3):147-58. PMid:21522210.

194. Fitzgerald GK, Axe MJ, Snyder-Mackler L. A decisionmaking scheme for returning patients to high-level activity with nonoperative treatment after anterior cruciate ligament rupture. Knee Surg Sports Traumatol Arthrosc. 2000;8(2):76-82. http://dx.doi.org/10.1007/s001670050190. PMid:10795668.

195. Gustavsson A, Neeter C, Thomeé P, Silbernagel KG, Augustsson J, Thomeé R, et al. A test battery for evaluating hop performance in patients with an ACL injury and 
patients who have undergone ACL reconstruction. Knee Surg Sports Traumatol Arthrosc. 2006;14(8):778-88. http:// dx.doi.org/10.1007/s00167-006-0045-6. PMid:16525796.

196. Neeter C, Gustavsson A, Thomeé P, Augustsson J, Thomeé R, Karlsson J. Development of a strength test battery for evaluating leg muscle power after anterior cruciate ligament injury and reconstruction. Knee Surg Sports Traumatol Arthrosc. 2006;14(6):571-80. http://dx.doi.org/10.1007/ s00167-006-0040-y. PMid:16477472.

197. Björklund K, Andersson L, Dalén N. Validity and responsiveness of the test of athletes with knee injuries: the new criterion based functional performance test instrument. Knee Surg Sports Traumatol Arthrosc. 2009;17(5):435-45. http://dx.doi. org/10.1007/s00167-008-0674-z. PMid:19039577.

198. Barber-Westin SD, Noyes FR. Factors used to determine return to unrestricted sports activities after anterior cruciate ligament reconstruction. Arthroscopy. 2011;27(12):1697-705. http://dx.doi.org/10.1016/j.arthro.2011.09.009. PMid:22137326.

199. Risberg MA, Holm I, Tjomsland O, Ljunggren E, Ekeland A. Prospective study of changes in impairments and disabilities after anterior cruciate ligament reconstruction. J Orthop Sports Phys Ther. 1999;29(7):400-12. http://dx.doi. org/10.2519/jospt.1999.29.7.400. PMid:10416180.

200. Ross MD, Irrgang JJ, Denegar CR, McCloy CM, Unangst ET. The relationship between participation restrictions and selected clinical measures following anterior cruciate ligament reconstruction. Knee Surg Sports Traumatol Arthrosc. 2002;10(1):10-9. http://dx.doi.org/10.1007/s001670100238. PMid:11819015.

201. Mizner RL, Petterson SC, Clements KE, Zeni JA Jr, Irrgang JJ, Snyder-Mackler L. Measuring functional improvement after total knee arthroplasty requires both performance-based and patient-report assessments: a longitudinal analysis of outcomes. J Arthroplasty. 2011;26(5):728-37. http://dx.doi. org/10.1016/j.arth.2010.06.004. PMid:20851566.

202. Clark NC. Functional performance testing following knee ligament injury. Phys Ther Sport. 2001;2(2):91-105. http:// dx.doi.org/10.1054/ptsp.2001.0035.

203. Reinke EK, Spindler KP, Lorring D, Jones MH, Schmitz L, Flanigan DC, et al. Hop tests correlate with IKDC and KOOS at minimum of 2 years after primary ACL reconstruction. Knee Surg Sports Traumatol Arthrosc. 2011;19(11):1806-16. http://dx.doi.org/10.1007/s00167011-1473-5. PMid:21445595.

204. Irrgang JJ, Snyder-Mackler L, Wainner RS, Fu FH, Harner $\mathrm{CD}$. Development of a patient-reported measure of function of the knee. J Bone Joint Surg Am. 1998;80(8):1132-45. PMid:9730122.

205. Hopper DM, Goh SC, Wentworth LA, Chan DYK, Chau JHW, Wootton GJ, et al. Test-retest reliability of knee rating scales and functional hop tests one year following anterior cruciate ligament reconstruction. Phys Ther Sport. 2002;3(1):10-8. http://dx.doi.org/10.1054/ptsp.2001.0094.

206. Hambly K, Griva K. IKDC or KOOS: which one captures symptoms and disabilities most important to patients who have undergone initial anterior cruciate ligament reconstruction? Am J Sports Med. 2010;38(7):1395-404. http://dx.doi.org/10.1177/0363546509359678. PMid:20351201.
207. Anderson AF, Irrgang JJ, Kocher MS, Mann BJ, Harrast JJ; International Knee Documentation Committee. The International Knee Documentation Committee Subjective Knee Evaluation Form: normative data. Am J Sports Med. 2006;34(1):128-35. http://dx.doi.org/10.1177/0363546505280214. PMid:16219941.

208. Langford JL, Webster KE, Feller JA. A prospective longitudinal study to assess psychological changes following anterior cruciate ligament reconstruction surgery. $\mathrm{Br} \mathrm{J}$ Sports Med. 2009;43(5):377-81. http://dx.doi.org/10.1136/ bjsm.2007.044818. PMid:19019910.

209. Webster KE, Feller JA, Lambros C. Development and preliminary validation of a scale to measure the psychological impact of returning to sport following anterior cruciate ligament reconstruction surgery. Phys Ther Sport. 2008;9(1):9-15. http://dx.doi.org/10.1016/j. ptsp.2007.09.003. PMid:19083699.

210. Myer GD, Martin L Jr, Ford KR, Paterno MV, Schmitt LC, Heidt RS Jr, et al. No association of time from surgery with functional deficits in athletes after anterior cruciate ligament reconstruction: evidence for objective return-tosport criteria. Am J Sports Med. 2012;40(10):2256-63. http:/ dx.doi.org/10.1177/0363546512454656. PMid:22879403.

211. Petersen W, Zantop T. Return to play following ACL reconstruction: survey among experienced arthroscopic surgeons (AGA instructors). Arch Orthop Trauma Surg. 2013;133(7):969-77. http://dx.doi.org/10.1007/s00402-0131746-1. PMid:23604790.

212. Narducci E, Waltz A, Gorski K, Leppla L, Donaldson M. The clinical utility of functional performance tests within one-year post-acl reconstruction: a systematic review. Int J Sports Phys Ther. 2011;6(4):333-42. PMid:22163095.

213. Nawasreh ZH, White K, Logerstedt D, Snyder-Mackler L. Knee Performance and Function at 6 Months Predict Return to Preinjury Activity Level One Year after Anterior Cruciate Ligament Reconstruction. J Orthop Sports Phys Ther. 2014;44(1):A60.

214. Di Stasi S, Myer GD, Hewett TE. Neuromuscular training to target deficits associated with second anterior cruciate ligament injury. J Orthop Sports Phys Ther. 2013;43(11):77792. http://dx.doi.org/10.2519/jospt.2013.4693. PMid:24175599.

215. Logerstedt D, Di Stasi S, Grindem H, Lynch A, Eitzen I, Engebretsen L, et al. Self-reported knee function can identify athletes who fail return-to-activity criteria up to 1 year after anterior cruciate ligament reconstruction: a delaware-oslo ACL cohort study. J Orthop Sports Phys Ther. 2014;44(12):914-23. http://dx.doi.org/10.2519/ jospt.2014.4852. PMid:25347228.

\section{Correspondence \\ David Logerstedt}

University of the Sciences

Department of Physical Therapy

108 Woodland, $600 \mathrm{~S} 43^{\text {rd }} \mathrm{St}$

Philadelphia, PA 19104, USA

e-mail: d.logerstedt@usciences.edu 